\title{
Dok. 2. \\ Program prac prezydencji szwedzkiej w Unii Europejskiej 1 lipca-31 grudnia 2009 r.
}

\begin{abstract}
Część I.
Podjęcie wyzwania

„Unia Europejska stoi na progu kluczowego okresu. Wspólnie musimy radzić sobie z kryzysem gospodarczym i bezrobociem, lecz także zjednoczyć świat w celu sprostania zmianom klimatycznym. Prezydencja szwedzka jest gotowa podjać to wyzwanie".
\end{abstract}

Premier Fredrik Reinfeldt

Współpraca europejska nieczęsto była tak ważna jak ma to miejsce obecnie. Żyjemy w czasach, w których świat wokół nas zmienia się gwałtownie i w którym do głównych wspólnych wyzwań należy podchodzić zarówno globalnie jak i regionalnie. Musimy pracować wspólnie na rzecz Europy, która bierze na siebie odpowiedzialność za gospodarkę, dobrobyt, środowisko, bezpieczeństwo oraz pokój. Współpraca wewnątrz UE musi być rozwijana w obszarach, w których przynosi to wartość dodaną.

Szwecja będzie sprawować prezydencję w Radzie Unii Europejskiej w drugiej połowie 2009 r. Wizją szwedzkiej prezydencji jest silna i skuteczna Europa, w której uwaga skupia się na wspólnej odpowiedzialności za sprostanie dzisiejszym i jutrzejszym wyzwaniom, włączając gotowość do zarządzania kryzysem.

Okres nadchodzących sześciu miesięcy będzie charakteryzować się zarówno zmianami jak i odnową. Nowo wybrany Parlament Europejski rozpocznie swą pracę i mianowana zostanie nowa Komisja. Warunki współpracy ulegną zmianie jeżeli Traktat z Lizbony wejdzie w życie. Do największych i najistotniejszych wyzwań należą gospodarka, zatrudnienie oraz klimat - zagadnienia, które dotyczą każdego obywatela UE. Poniżej przedstawione zostały główne cele prezydencji:

- UE musi wyjść z kryzysu gospodarczego z silniejszą pozycją. Świat doświadcza jednego z najbardziej poważnych kryzysów finansowych i gospodarczych we współczesnych czasach. Sytuacja ekonomiczna pozostaje bardzo trudna. Finanse publiczne stają się coraz bardziej nadwyrężone, a jesienią spodziewany jest wzrost bezrobocia. Konieczna jest wspólna zdolność do podejmowania działań zarówno w obszarach finansowych i gospodarczych jak również na rynku pracy jeżeli UE ma być w stanie skutecznie stawić czoła kryzysowi. Prezydencja i Państwa Członkowskie będą dalej wspólnie pracować w celu zwalczania negatywnego wpływu kryzysu na wzrost i miejsca pracy mając na celu osiągnięcie ożywienia gospodarczego w możliwie najbliższej perspektywie.

- UE musi nadal brać odpowiedzialność za zagrożenia klimatyczne. Wielkim wyzwaniem naszych czasów jest zapobieganie zagrożeniom klimatycznym i zwalczanie zmian klimatycznych. Zmiany klimatyczne wywierają poważne skutki na społeczeństwa, jednostki i przyszłe pokolenia. UE będzie kontynuować globalne starania na 
rzecz klimatu. Zadaniem prezydencji, jak również innych stron, jest praca na rzecz przyjęcia nowego porozumienia klimatycznego podczas międzynarodowych negocjacji klimatycznych prowadzonych w grudniu w Kopenhadze. Podjęcie obydwu powyższych działań wymaga ambitnego planu dla EU. Jednocześnie jednak stanowi to możliwość wzmocnienia przez UE swojej konkurencyjności, stworzenia nowych miejsc pracy oraz przyczynienia się do wyższej jakości środowiska naturalnego. Celem prezydencji jest rozwinięcie współpracy pomiędzy różnymi obszarami polityk w celu połączenia dodatniego wzrostu gospodarczego z ograniczonym obciążeniem klimatu i środowiska naturalnego. Wymaga to zaawansowanych instrumentów, zwiększenia zdolności do innowacji i odnowienia europejskiego sektora gospodarczego.

Europa napotyka na szereg innych wyzwań. UE musi kontynuować rozwój w kierunku dążenia do Europy bardziej bezpiecznej i otwartej. Prezydencja pragnie rozwijać współpracę transgraniczną w celu ochrony wartości demokratycznych i praw jednostki, a także sprostać wyzwaniom, które stoją przed Europa. W celu zwalczania międzynarodowej przestępczości konieczne są połączone wysiłki. UE musi ustanowić bardziej skuteczną politykę azylową i migracyjną. Celem prezydencji jest rozwój współpracy w obszarze wymiaru sprawiedliwości i spraw wewnętrznych poprzez Program Sztokholmski, który zostanie przyjęty jesienią. Kraje basenu Morza Bałtyckiego napotykają obecnie na wspólne wyzwania. Jednym z nich jest zarządzanie pilnymi, poważnymi problemami środowiska naturalnego związanymi z Morzem Baltyckim. Kolejnym wyzwaniem jest znalezienie sposobu, w jaki możemy przekształcić region Morza Bałtyckiego w silniejszy region wzrostu i rozwoju. Prezydencja będzie rozwijać współpracę regionalną pomiędzy UE a państwami bałtyckimi będącymi obszarem pilotażowym. Dzięki stosowaniu powszechnych uregulowań nastąpi poprawa środowiska naturalnego i wzmocnienie konkurencyjności regionu. Celem prezydencji jest przyjęcie przez UE strategii dla regionu Morza Battyckiego.

Prezydencja będzie prowadzić prace nad wzmocnieniem roli UE jako globalnego aktora z przejrzystą agendą w dziedzinie pokoju, rozwoju, demokracji i praw człowieka. Najbardziej skutecznym sposobem przyczynienia się do pokoju, demokracji i dobrobytu w Europie jest rozszerzanie, nad którym prace są kontynuowane. Szwedzkie priorytety są oparte na trójstronnej współpracy prezydencji z Francją i Republiką Czeską, jak również na 18-miesięcznym programie zatwierdzonym w czerwcu 2008 roku. Jesienią przeprowadzone zostaną intensywne prace koncentrujące się na wszystkich zagadnieniach agendy UE. Priorytetowe zagadnienia dla każdej konfiguracji Rady zostały wymienione w części 2 niniejszego programu.

\section{Gospodarka i zatrudnienie - EU wychodzi z kryzysu gospodarczego silniejsza}

Globalny kryzys finansowy uderzył w Europę z pełną siłą. Wraz z jego nadejściem nastapił malejący wzrost, przypadki bankructwa i bezrobocie. Kryzys finansowy i gospodarczy zajmuje ważne miejsce na agendzie UE od czasu zaobserwowania jego pierwszych skutków. UE pomogła uniknąc załamania finansowego dzięki wspólnym działaniom. UE zgodziła się na plan ożywienia mający na celu zrównoważenie recesji, zmniejszenie jej wpływu na zatrudnienie i poprawę konkurencyjności. Prezydencja bę- 
dzie kontynuować prace rozpoczęte pod przewodnictwem Francji i Republiki Czeskiej. Celem jest praca nad odbudową zaufania do rynków finansowych, zwalczanie negatywnych wpływów kryzysu na wzrost i zatrudnienie oraz tworzenie długookresowych rozwiązań służących zrównoważonemu wzrostowi, zatrudnieniu i otwartym rynkom.

Czas kryzysu pociaga za sobą poważne wyzwania w odniesieniu do finansów publicznych. Prawidłowa dyscyplina budżetowa promuje solidny rozwój gospodarczy. W związku z powyższym, kluczową kwestią jest omówienie sposobu, w jaki Państwa Członkowskie mogą przywrócić porządek w finansach publicznych.

Kryzys ekonomiczny ma wymiar globalny i wymaga globalnej odpowiedzi. G-20 (19 największych światowych gospodarek plus UE) jest ważnym forum. Jesienią G-20 zajmie się zagadnieniami związanymi z zasobami międzynarodowych instytucji finansowych, regulacją i nadzorem rynków finansowych, pracami przeciw szkodliwej konkurencji podatkowej i zwiększeniu zasobów gospodarki światowej. Prezydencja będzie prowadzić prace nad wspólnym stanowiskiem UE przed spotkaniami G-20.

\section{Więcej miejsc pracy i więcej zatrudnionych osób}

Wraz ze spowolnieniem gospodarczym spodziewane są dalsze redukcje zatrudnienia i ograniczanie miejsc pracy. Będzie to miało poważny negatywny wpływ na jednostki i społeczeństwa jako całość. Kryzys ekonomiczny wymaga skutecznych działań podejmowanych w celu ograniczenia i złagodzenia jego skutków. Musimy unikać powtarzania błędów poprzednich dekad, które prowadzą do długookresowego wykluczenia lub do przedwczesnego opuszczania przez ludzi rynku pracy. W związku z powyższym, prezydencja będzie stawiała na działania odnoszące się do rynku pracy jednocześnie ograniczające bezrobocie, zmniejszające wykluczenie i powodujące powrót ludzi do pracy będące podstawą wysokiego poziomu długookresowego zrównoważonego zatrudnienia. Odpowiedzialność za politykę rynku pracy spoczywa na Państwach Członkowskich. Wartością dodaną UE jest wymiana doświadczeń i zaangażowanie przy podejmowaniu działań na szczeblu krajowym, które zwiększają zatrudnienie kobiet i mężczyzn w całej UE. Istnieje ogromna potrzeba rozwiązania problemu bezrobocia, zarówno wspólnie jak i w każdym Państwie Członkowskim. W krótkim okresie należy ułatwiać szybki powrót do pracy, zaś w długim okresie należy umacniać możliwość zatrudnienia jednostki i jej pozycję na rynku pracy. Aktywna polityka rynku pracy służąca lepszemu dostosowaniu i mobilności na rynku pracy UE, skuteczniejsze dopasowanie, zwiększony rozwój kompetencji oraz większa liczba przedsiębiorców są ważnymi czynnikami w radzeniu sobie $\mathrm{z}$ kryzysem na rynku pracy zarówno w perspektywie krótko- i dlugookresowej. W odniesieniu do sektora biznesowego, ważnymi czynnikami są praca nad lepszymi uregulowaniami i lepszymi warunkami dla mniejszych przedsiębiorstw a także stabilizacja finansowa i łatwiejszy dostęp do kapitału.

\section{Wydajne rynki finansowe dzięki lepszemu nadzorowi i regulacji}

Obecny kryzys nie byłby aż tak poważny, gdyby organy nadzoru mogły przewidzieć ryzyko na rynkach finansowych. W związku z tym, konieczne są nowe zasady oraz wzmocnione organy nadzoru. Celem prezydencji jest osiagnięcie porozumienia 
w kwestii formy nowej struktury nadzoru obejmującej ustanowienie europejskiego organu nadzoru stabilności systemu finansowego jako całości. Nowa struktura zawiera również propozycję europejskiego systemu nadzoru finansowego na poziomie mikro, który zagwarantuje bardziej skuteczny nadzór bankowości transgranicznej i wzmocnioną współpracę pomiędzy krajowymi organami nadzoru.

\section{Wzrost długookresowy i zatrudnienie w nadchodzącej dekadzie}

Równolegle z odpowiedzią UE na poważny kryzys ekonomiczny należy pamiętać o wyzwaniach długookresowych. Jedynym sposobem, w jaki możemy strzec naszych systemów opieki społecznej w Europie jest wysoki poziom zatrudnienia i zdrowe finanse publiczne. Kryzys gospodarczy pokazał znaczenie długookresowych reform służących ułatwieniu dostosowania, rozwojowi nowych przedsiębiorstw i możliwości zatrudnienia. Kryzys daje również możliwość tworzenia gospodarki łączącej wzrost $\mathrm{z}$ równowagą środowiska naturalnego. Ożywienie gospodarcze jest oparte na otwartych, integrujących i wydajnych rynkach, zarówno wewnątrz UE jak i poza nią. Należy ułatwić konsumentom i przedsiębiorcom wykorzystanie korzyści plynących z rynku wewnętrznego. Przyjazny klimat dla biznesu oparty na nieskomplikowanych zasadach sprzyja nowym i rozwijającym się przedsiębiorstwom. Badania i innowacje stwarzaja nowe obszary rozwoju. Wydajne rynki pracy połączone $z$ nowoczesnymi systemami ubezpieczeń społecznych sprawią, że dostosowanie będzie prostsze zarówno dla przedsiębiorstw jak i dla jednostek. UE napotyka na szereg poważnych wyzwań czekających na nią w przyszłej dekadzie: sprostanie zwiększonej globalnej konkurencji, przywrócenie równowagi finansów publicznych oraz sprostanie wyzwaniu stawianemu przez problem starzejącej się populacji. Konieczna jest nowa skoncentrowana strategia wzrostu i dobrobytu w długim okresie. Prezydencja zamierza położyć podwaliny dla następnej strategii dla zrównoważonego wzrostu i miejsc pracy, t.j. następcy Strategii Lizbońskiej. Trwają prace ukierunkowane na osiagnięcie podczas szwedzkiej prezydencji porozumienia w sprawie ogólnych wyzwań i obszarów. Decyzja w sprawie następnej strategii zostanie podjęta wiosną $2010 \mathrm{r}$. w trakcie prezydencji hiszpańskiej.

\section{Klimat - wdrożenie nowego porozumienia klimatycznego}

Emisje gazów cieplarnianych ulegają zwiększeniu, a klimat zmienia się obecnie szybciej niż się tego spodziewano na podstawie badań. Ryzyko nieuniknionych zmian w systemie klimatycznym zwiększa się z każdym dniem. Globalne ocieplenie jest zagrożeniem dla środowiska, które wymaga globalnych rozwiązań. Emisje są równie szkodliwe bez względu na to, gdzie występują. Cechą wspólną zagrożeń jest fakt, że większość z nich wywiera poważny negatywny wpływ na życie na ziemi. Ograniczenie emisji gazów cieplarnianych na skalę globalną wymaga działań podejmowanych we wszystkich krajach. Jest to wyzwanie wymagające konsensusu w kwestii działań długookresowych podejmowanych we wszystkich częściach społeczeństwa, na szczeblu lokalnym, krajowym i międzynarodowym. Punktem wyjścia dla UE jest Międzyrządowy Zespół ds. Zmian Klimatu (IPCC), który stwierdza, że poziomy emisji globalnych muszą ulec zmniejszeniu co najmniej o połowę w latach 1990-2050 w celu 
ograniczenia zwiększenia średniej temperatury do dwóch stopni Celsjusza. Oznacza to, że świat uprzemysłowiony musi zredukować poziomy emisji o $25-40 \%$ do roku 2020 oraz o 80-95\% do roku 2050 w porównaniu do poziomu z 1990 roku. Zdaniem IPCC ważne jest również stworzenie warunków służących krajom rozwijającym się do zmniejszenia poziomów emisji o 15-30\% do roku 2020 w porównaniu do sytuacji, która mogłaby mieć miejsce w przypadku, gdy działania nie byłyby podjęte. Zmiana klimatu stanowi wyzwanie wymagające współpracy i wspólnych działań w Europie oraz na całym świecie. Jeżeli podejmiemy globalne działania służące przejściu na energie, która ogranicza zależność od paliw kopalnych, możliwe będzie uniknięcie poniesienia w przyszłości poważnych kosztów związanych z katastrofami klimatycznymi. Kraje uprzemysłowione ponoszą szczególną odpowiedzialność za objęcie przywództwa w związku z faktem, że poziomy naszych emisji gazów cieplarnianych są wyższe w porównaniu z mniej zamożnymi częściami świata, a także z powodu naszej lepszej sytuacji gospodarczej.

\section{Globalne porozumienie w sprawie redukcji emisji.}

Ramowa Konwencja Narodów Zjednoczonych w sprawie zmian klimatu stanowi sedno międzynarodowych starań podejmowanych na rzecz klimatu. Niemal wszystkie państwa świata uczestniczą w pracach nad Konwencją Klimatyczną. Protokół z Kioto zawiera zobowiązania w kwestii redukcji emisji do 2012 roku przez państwa uprzemysłowione. Podczas Konferencji Stron Konwencji mającej miejsce w Kopenhadze w grudniu 2009 roku podjęta zostanie decyzja w sprawie nowych zobowiązań na okres przypadający po roku 2012. Najważniejszym celem prezydencji jest przywództwo UE i uzgodnienie podczas spotkania w Kopenhadze, wspólnie z innymi stronami, międzynarodowego porozumienia klimatycznego. UE była i jest nastawiona proaktywnie w wysiłkach na rzecz klimatu, stojących przed spotkaniem w Kopenhadze. W trakcie prezydencji francuskiej przyjęty został ambitny pakiet legislacyjny w sprawie sprostania zagrożeniu klimatycznemu przez samą UE. UE uzgodniła, że zmniejszy do 2020 roku emisję dwutlenku węgla o 30\% w porównaniu z poziomami z 1990 roku jeżeli inne uprzemysłowione państwa poczynią podobne zobowiązania. W przeciwnym razie UE zredukuje do 2020 roku jednostronnie poziomy emitowanego przez nią dwutlenku węgla o $20 \%$ w porównaniu do 1990 roku. Jednocześnie oczywistym jest, że UE, na którą przypada 14\% światowych emisji nie może zwalczać zmian klimatycznych samodzielnie. Dlatego też ważne jest wdrożenie nowego porozumienia klimatycznego.

\section{Dostosowanie i finansowanie w celu uzyskania ogólnej akceptacji.}

W ramach negocjacji klimatycznych pozostaje szereg istotnych problemów wymagających rozpatrzenia. Pierwszym z nich jest sposób, w jaki państwa uprzemysłowione mają osiągnąć redukcję poziomów emisji o 25-40\%. Konieczne są adekwatne i wiążące zobowiązania w sprawie przyszłych redukcji emisji przez kraje uprzemysłowione. Drugim jest konieczność zawarcia porozumienia w sprawie ograniczeń emisji przez rozwijające się gospodarki. Środki podejmowane przez te kraje w perspektywie śred- 
niookresowej są także kluczowe w odniesieniu do perspektywy odwrócenia globalnego trendu zwiększonych emisji i utrzymania realizacji celu obniżenia temperatury o dwa stopnie Celsjusza. Trzecim istotnym problemem, który należy rozwiązać jest finansowanie dostosowań, środków redukcji emisji oraz przeniesienia technologii do krajów rozwijających się. Środki dostosowawcze są konieczne, aby uporać się ze szkodami już wyrządzonymi przez zmiany klimatyczne i tymi, które zmiany te spowodują w przeszłości. Konieczny jest rozwój rynków handlu emisjami i instrumentów rynkowych oraz zwiększone finansowanie ze środków publicznych będące uzupełnieniem. Istnieje kilka propozycji odnośnie do sposobu wygenerowania środków finansowych, zarządzania nimi i administrowania, które będą dalej omawiane jesienią.

\section{Rola UE}

W celu osiagnięcia postępów w negocjacjach konieczne jest ciągłe porozumienie w UE. Przyjęcie pakietu klimatycznego i energetycznego UE oznacza, że UE wyraziła zgodę na ambitną politykę klimatyczną. Konieczny jest rozwój polityki UE w odniesieniu do zagadnień takich jak finansowanie, a nie tylko odpowiadanie na oczekiwania krajów rozwijających się wobec UE. Potrzebujemy szerokiego porozumienia po 2012 roku. UE potrzebuje również sprawić, aby pozostałe uprzemysłowione kraje zobowiązały się do ambitnych zamierzeń służących redukcji emisji. Aby móc uczestniczyć w międzynarodowych negocjacjach konieczne jest opracowanie nowych stanowisk w ramach UE. Podstawową przesłanką prezydencji jest promocja jedności w UE i utrzymanie odpowiedzialności ponoszonej przez UE jako pozytywnej siły w negocjacjach klimatycznych, w zgodzie i poszanowaniu krajowych warunków. UE ma istotną rolę do odegrania w odniesieniu do krajów rozwijających się, które są często szczególnie obarczone ryzykiem i narażone na zmiany klimatu. Główną kwestią, zarówno przed Szczytem w Kopenhadze jak i w dhuższym okresie, jest potrzeba skutecznego wsparcia w celu ułatwienia dostosowania krajów i ludzi do skutków zmian klimatycznych. Komisja ds. Zmian Klimatycznych i Rozwoju powstała z inicjatywy rządu szwedzkiego niesie istotny wkład. Prezydencja przyczyni się do postępów czynionych przez UE w tych kwestiach, które są istotne również dla projektu przyszłego rozwoju współpracy pomiędzy Państwami Członkowskimi a Komisją Europejską. Ponadto, ambicją prezydencji jest, aby silne przywództwo w UE promowało przejście na eko-efektywną gospodarkę, w której umacniane są możliwości wzrostu i wykorzystywane rozważania związane ze zmianami klimatycznymi. Prezydencja zainicjuje dyskusję służącą temu rozwojowi.

\section{Wymiar Sprawiedliwości i Sprawy Wewnętrzne - Sztokholmski Program stojq̨cy na straży bezpieczeństwa i praw jednostki}

Współpraca UE w zakresie Wymiaru Sprawiedliwości i Spraw Wewnętrznych ulega stopniowemu rozwojowi. Stosowane są wspólne przepisy prawne i metody służące zagwarantowaniu prawnie uzasadnionej współpracy transgranicznej. Jednym z wyzwań prezydencji jest dalszy rozwój współpracy w obszarach, w których współpraca transgraniczna przynosi wartość dodaną. Ambicją prezydencji jest przyjęcie nowego 
strategicznego programu działania dla całego obszaru polityki. Program, który będzie trzecim z serii, ma określić ramy i punkt centralny współpracy w UE na lata 2010-2014 w obszarach takich jak policja, zagadnienia graniczne i celne, zagadnienia prawne i azylowe oraz polityka migracyjna i wizowa. Wizją pracy w ramach Programu Sztokholmskiego jest bardziej bezpieczna i otwarta Europa, która stoi na straży praw jednostki.

\section{Europa obywateli}

Współpraca w ramach UE musi oferować rozwiązania codziennych problemów ludzi w zakresie swobodnego przepływu osób. Obywatele UE przemieszczają się w Europie w coraz większym stopniu. Coraz większa liczba osób pracuje za granicą i zakłada rodziny z obywatelami innych krajów. W związku z tym istotne jest stworzenie większej przejrzystości w kwestiach takich jak zasady, które należy stosować w celu ułatwienia swobodnego przepływu osób.

\section{Wspólpraca w celu zwalczania przestępczości}

Aby skutecznie zwalczać przestępczość organy ścigania muszą mieć możliwość współpracy transgranicznej, zarówno pomiędzy Państwami Członkowskimi UE jak i pomiędzy UE i resztą świata. Niezmiernie ważne są środki służące poprawie wiedzy i wymianie informacji, które są konieczne, aby móc zapobiegać, wykrywać i badać przestępczość. Ambicją prezydencji jest zrównoważenie skutecznego zwalczania przestępczości ze środkami gwarantującymi prawa jednostki. Wspólpraca w ramach UE musi koncentrować się w większym stopniu na działaniach służących jednostce, obejmujących zarówno prawa osób będących ofiarami przestępstw jak i tych, które są podejrzewane o popełnienie przestępstwa.

\section{Zagadnienia azylowe i migracyjne na przyszlość}

UE poczyniła olbrzymi postęp w pracach nad wspólną polityką azylową. Prezydencja będzie promować wspólny system azylowy, który cechuje się pewnością prawną i przejrzystością. Istotnym jest by wspólne regulacje były stosowane w zamierzony sposób w Państwach Członkowskich w odniesieniu do przyjmowania, przetwarzania i odsyłania wniosków o azyl. Kolejnym ważnym celem jest stworzenie wspólnych regulacji dotyczących przesiedleń w celu pomocy osobom potrzebujacym ochrony, lecz nie będących w stanie dostać się do UE. Tak jak ma to miejsce w przypadku spraw azylowych, sprawy migracyjne są potraktowane priorytetowo. Populacja UE się starzeje. Pomimo bezrobocia, UE potrzebuje migracji zarobkowej, szczególnie w perspektywie długookresowej. Program Sztokholmski powinien w związku z tym zawierać środki, które pozwolą na zwiększenie migracji zarobkowej na teren UE. Globalne Podejście do Migracji UE jest ważnym narzędziem służącym wzmocnieniu pozytywnego związku pomiędzy migracją a rozwojem, pogłębieniu dialogu i współpracy z krajami spoza UE i zwalczaniu nielegalnej imigracji bez ograniczania możliwości starania się o azyl. 


\section{Strategia UE dla regionu Morza Baltyckiego, czystsze środowisko morskie i bardziej konkurencyjny region}

UE i jej regiony wzajemnie się wspierają. Zamierzeniem prezydencji jest rozwój makroregionalnej współpracy w ramach UE. Celem jest przyjęcie Strategii UE dla regionu Morza Bałtyckiego, która przyczyni się do czystszego morza i do większej dynamiki gospodarczej. Tłem strategii jest fakt, że region Morza Bałtyckiego boryka się z poważnymi wyzwaniami, którym najlepiej sprostać wspólnie. W związku z faktem, że osiem z dziewięciu Państw Morza Bałtyckiego jest państwami członkowskimi UE, w celu sprostania tym wyzwaniom możliwe jest stosowanie regulacji UE.

\section{Wyzwania transgraniczne wymagają wspólnych rozwiązań}

Jednym z głównych wyzwań jest degradacja środowiska naturalnego w Morzu Bałtyckim i wokół niego. Eutrofizacja, kwitnienie alg, przełowienie i zanieczyszczenie nie są problemami, którymi może zająć się tylko jeden kraj. Morze Bałtyckie jest unikalnym słonym morzem śródlądowym, w którym równowaga ekosystemu może zostać łatwo naruszona. Strategia UE dla Regionu Morza Bałtyckiego ma na celu wspólną pracę nad tymi wyzwaniami z wykorzystaniem takich środków jak stopniowe wycofywanie fosforanów z detergentów do prania i mycia naczyń, ograniczanie szkodliwych skutków wycieku nawozów lub innych składników odżywczych oraz skuteczniejsza kontrola połowów. Do pozostałych wyzwań należy niepełne wykorzystywanie potencjału wzrostu regionu oraz wywarcie przez kryzys finansowy poważnego wpływu na obszar sąsiadujący z regionem Morza Bałtyckiego. Tak jak w przypadku innych obszarów, lepsza koordynacja będzie korzystna dla regionu Morza Bałtyckiego. Potrzebne są wspólne inicjatywy prowadzone na większą skalę w obszarze badań, innowacji i przedsiębiorczości. Można to osiągnąć poprzez stosowanie takich środków jak ułatwienia dla małych przedsiębiorstw, usuwanie barier handlowych i łączenie zasobów. Konieczny jest wspólny rozwój rynków energetycznych, infrastruktury i systemów transportowych. Potrzebne są również inwestycje w technologie informatyczne i komunikację elektroniczną. Kolejnym problemem, który wymaga wspólnego rozwiązania jest przestępczość transgraniczna. W celu zwiększenia bezpieczeństwa $\mathrm{w}$ regionie konieczna jest lepsza współpraca w celu zwalczania handlu ludźmi i innych rodzajów przestępczości zorganizowanej. Ponadto, bezpieczeństwo w regionie Morza Bałtyckiego mogłoby zostać zwiększone poprzez takie działania jak skoordynowany nadzór morski.

\section{Nowe narzędzie służące bliższej wspólpracy}

Oczekuje się, że Strategia UE dla regionu Morza Bałtyckiego będzie narzędziem wyposażonym w konkretne działania, które mogą mieć rzeczywisty wpływ na codzienne życie ludzi. Intencją jest aby strategia ta posłużyła jako źródło inspiracji dla innych regionów UE. Intencją strategii jest połączenie inicjatyw UE, instrumentów polityki i zasobów w celu przyczynienia się do osiaggania korzyści przez region Morza Bałtyckiego, jego środowiska naturalnego i konkurencyjności. Strategia UE dla regionu Morza Bałtyckiego będzie wspierać zwiększoną współpracę, lepsze stosowanie prawa wspólnotowego i bardziej wydajne wykorzystanie istniejących środków UE. 


\section{UE, jej squsiedztwo i świat}

UE została ustanowiona w celu zagwarantowania pokoju i rozwoju gospodarczego w Europie. Unia w coraz większym stopniu przyjmuje odpowiedzialność za promowanie pokoju, stabilności i rozwoju w naszym regionie i na całym świecie. UE staje się głosem coraz bardziej słyszalnym w świecie poprzez dialog, negocjacje oraz środki zachęcające.

\section{Rola UE na arenie światowej}

Prezydencja będzie kontynuować prace nad wzmocnieniem pozycji UE jako globalnego aktora posiadającego przejrzystą agendę dla pokoju, rozwoju, demokracji i praw człowieka. Pragniemy pogłębiać zdolność UE do działania w obliczu międzynarodowych kryzysów oraz umacniania współpracy z ważnymi partnerami. Chcemy pomóc zagwarantować spójność pomiędzy wspólnymi inicjatywami polityki zagranicznej a bezpieczeństwem i handlem oraz rozwojem inicjatyw polityki. Stosunki z sąsiadami UE są niezmiernie istotne. W związku z tym trwają prace nad opracowaniem Europejskiej Polityki Sąsiedztwa. Szczególna uwaga zostanie poświęcona wdrożeniu Partnerstwa Wschodniego. Celem działania są również prace nad osiągnięciem bliższej współpracy z naszymi sąsiadami w regionie Morza Śródziemnego, na przykład w ramach Unii dla Śródziemnomorza. Na arenie światowej, prezydencja będzie wykorzystywać nowe perspektywy dla pogłębienia dialogu transatlantyckiego. Istotną kwestią jest, aby UE dalej zwiększała swoje zaangażowanie wobec Afganistanu i Pakistanu. Istnieje potrzeba zintensyfikowania roli UE na Bliskim Wschodzie. Musimy być przygotowani do zażegnywania kryzysów w Afryce. Do ważnych zagadnień, w których musi nastappić postęp, zaliczane jest wzmocnienie zdolności krajów rozwijających się do radzenia sobie ze zmianami klimatycznymi oraz wzmocnienie wsparcia UE dla budowania demokracji w stosunkach zewnętrznych. Ponadto, prezydencja będzie stawiała na negocjacje handlowe, przede wszystkim na szybkie zakończenie Rundy z Doha, a także osiagnięcie postępów w negocjacjach w sprawie wolnego handlu. W trakcie prezydencji planowane są spotkania na szczycie z wieloma ważnymi parterami: Brazylią, Chinami, Indiami, Rosja, Republiką Południowej Afryki oraz Stanami Zjednoczonymi.

\section{Ciągle rozszerzanie}

Proces ciagłego rozszerzania odgrywa strategiczne znaczenie w zagwarantowaniu pokoju i postępu w otwartej, zjednoczonej Europie. W związku z tym, kluczowe znaczenie ma dotrzymywanie przez UE swoich zobowiązań i zasad ustanowionych w obszarze rozszerzania. Tempo procesu integracji UE zostanie ustalone w wyniku procesu reform przeprowadzanych w każdym kraju. Negocjacje pomiędzy Chorwacją a UE mogłyby wejść w końcową fazę jesienią. Prezydencja dąży do osiagania ciągłych postępów w negocjacjach akcesyjnych z Turcją. Rozwiązanie kwestii Cypru znacznie przyspieszyłoby proces integracji Turcji z UE. Prezydencja będzie również pracować nad osiagnięciem dalszych postępów w procesie integracji krajów Bałkanów Zachodnich, zgodnie z postępem reform w każdym kraju i ustanowionych procedur. 


\section{Nowy Parlament, Komisja i Traktat z Lizbony}

Na prace prowadzone jesienią będą miały wpływ szczególne warunki instytucjonalne. Po wyborach przeprowadzonych w czerwcu uformuje się nowy Parlament Europejski i powołana zostanie nowa Komisja. Jeżeli Traktat z Lizbony zostanie ratyfikowany przez wszystkie Państwa Członkowskie, fundamenty UE ulegną zmianie. Traktat z Lizbony sprawi, że UE będzie bardziej skuteczna w swoich działaniach i bardziej demokratyczna. Zamierzeniem prezydencji jest działanie w sposób umożliwiający wprowadzenie Traktatu w pozytywnej atmosferze. Konieczne jest stworzenie odpowiednich warunków tak, aby stosowanie Traktatu z Lizbony przebiegało od samego początku skutecznie i bezproblemowo. Jesienią prezydencja będzie prowadzić bliską współpracę ze wszystkimi instytucjami oraz Państwami Członkowskimi. Prezydencja będzie także gotowa do prowadzenia dialogu i dyskusji z Parlamentem Europejskim na temat pracy Rady.

\section{Komentarze podsumowujące}

„Przyszła kolej Szwecji na objęcie roli kapitana. Naszym zamierzeniem jest osiaganie wyników w wielu kwestiach mając na uwadze dobro całej Europy. Będziemy to czynić poprzez otwartą i skuteczną prezydencję koncentrującą się na obywatelach" (Cecilia Malmström, Minister ds. Europejskich).

Przed Europą stoją dwa główne wyzwania: globalny kryzys gospodarczy oraz starania ukierunkowane na powstrzymanie zmian klimatycznych. W trakcie swojej prezydencji, Szwecja będzie ciężko pracować nad poczynieniem postępów w odniesieniu do tych jak i innych istotnych kwestii. Codzienna praca UE musi być otwarta, skuteczna i zorientowana na wyniki: otwarta poprzez przejrzystość i dostępność, skuteczna poprzez czynienie postępów w odniesieniu do tych zagadnień oraz zorientowana na wyniki poprzez podejmowanie działań $\mathrm{w}$ celu spełnienia celów i radzenia sobie $\mathrm{z}$ niespodziewanymi zdarzeniami.

\section{Część II. \\ Priorytety w ramach każdej konfiguracji Rady}

\section{Zagadnienia horyzontalne dla lepszej Unii Europejskiej GAERC - Sprawy ogólne}

Rada ds. Ogólnych zajmuje się sprawami międzysektorowymi UE i przygotowuje posiedzenia Rady Europejskiej. Jesienią w centrum uwagi znajdzie się kilka wyzwań, które staną przed Europą w przyszłości: sposób, w jaki należy postępować w długim okresie w odniesieniu do wzrostu i zatrudnienia, sposób, w jaki postępować ma ciągłe rozszerzanie UE zgodnie z ustanowionymi zasadami i wymogami, zrównoważony sposób rozwoju UE oraz w jaki sposób można rozwijać makroregionalną współpracę z wykorzystaniem Strategii dla regionu Morza Bałtyckiego. Rada ds. Ogólnych odpowiada za sprawy ogólne, które będą musiały być rozpatrywane, jeśli Traktat z Lizbony wejdzie w życie. 


\section{Strategia UE dla regionu Morza Baltyckiego - makroregion w UE}

Jedną z priorytetowych spraw stojących przed prezydencją jest przyjęcie Strategii UE dla regionu Morza Baltyckiego. Strategia UE dla regionu Morza Baltyckiego ma połączyć inicjatywy UE, instrumenty polityki oraz istniejące zasoby w sposób międzysektorowy w celu przyniesienia korzyści dla regionu Morza Bałtyckiego, jego środowiska naturalnego i rozwoju gospodarczego. Propozycja Komisji zostanie omówiona podczas konferencji ministerialnej odbywającej się we wrześniu w tym samym czasie, gdy Strategia będzie rozważana przez Radę. Zamierzeniem jest przyjęcie Strategii podczas posiedzenia Rady Europejskiej w październiku.

\section{Ciągle rozszerzanie}

Rozszerzanie jest głównym instrumentem UE służącym tworzeniu stabilności, demokracji i dobrobytu w Europie. Proces ciagłego rozszerzania ma strategiczne znaczenie dla zagwarantowania pokoju i postępów w otwartej i zjednoczonej Europie. Kluczowe znaczenie ma wywiązywanie się przez UE z powziętych zobowiązań i zasad ustanowionych w zakresie rozszerzania. Tempo tworzenia bliższych więzi z UE zostanie określone przez postępy reform w każdym kraju i ich dostosowanie do prawodawstwa UE. Bez obniżenia wymogów odnoszących się do członkostwa w UE, prezydencja przewiduje, że negocjacje Chorwacji prowadzone z UE mogłyby wejść w fazę końcową jesienią. Prezydencja dąży do osiągnięcia ciągłych postępów w negocjacjach prowadzonych w sprawie akcesji Turcji. Rozwiązanie kwestii Cypru miałoby pozytywny wpływ na proces integracji Turcji do UE. Ocena Komisji dotycząca postępów reform Byłej Jugosłowiańskiej Republiki Macedonii zaprezentowana w jesiennym raporcie o postępach będzie stanowić podstawę dla podejmowania wszelkich decyzji w sprawie dodatkowych kroków w procesie integracji kraju z UE. Prezydencja będzie pracować nad osiagnięciem dalszych konkretnych postępów dotyczących perspektyw członkostwa dla potencjalnych krajów kandydujących Bałkanów Zachodnich. Wnioski o członkostwo z regionu zostaną złożone w Radzie w celu podjęcia decyzji w sprawie zlecenia Komisji przygotowania opinii (avis) zgodnie z ustalonymi procedurami. Prezydencja będzie prowadzić działania wspierające proces reform w Kosowie.

\section{Strategia dla wzrostu i miejsc pracy na nadchodzącą dekadę}

Strategia Lizbońska stanowi wspólne ramy UE dla zrównoważonego wzrostu i zwiększania zatrudnienia. Jej celem jest stworzenie stabilności makroekonomicznej, wzmocnienie konkurencyjności poprzez inwestycje w badania i edukację, poprawa klimatu dla biznesu, wdrożenie rynku wewnętrznego, poprawa sposobu funkcjonowania rynku pracy oraz wzmocnienie spójności społecznej. Jesienią zostaną rozpoczęte prace nad strategią dla wzrostu i zatrudnienia na nadchodzacą dekadę. Celem prezydencji jest, aby przyszła strategia koncentrowała się na największych wyzwaniach w perspektywie długookresowej: przekształcenie UE w gospodarkę eko-wydajna, aby spełnić cele środowiskowe i klimatyczne, wzmocnienie globalnej konkurencyjności UE poprzez systemy otwartego handlu globalnego, zwalczanie skutków starzenia się populacji oraz 
przywrócenie zrównoważonych finansów publicznych. W oparciu o wkład kilku konfiguracji Rady, Rada ds. Ogólnych przygotuje omówienia i wnioski Rady Europejskiej odnoszące się do aspektu, na którym koncentruje się przyszła strategia.

\section{Zrównoważona Europa}

Zrównoważony rozwój oznacza poprawę standardów życia gwarantując przyszłym pokoleniom jednakowe możliwości odnoszące się do wysokiej jakości życia i dobrobytu. Strategia Zrównoważonego Wzrostu UE podkreśla związek pomiędzy kwestiami dotyczącymi środowiska naturalnego, społecznymi i ekonomicznymi. W oparciu o propozycję Komisji i inne rozważania, prezydencja będzie kontynuować Strategię Zrównoważonego Wzrostu UE, aby w grudniu umożliwić Radzie Europejskiej przyjęcie mapy drogowej na nadchodzące lata.

\section{Przejrzystość w UE}

Przejrzystość jest fundamentalnym warunkiem zaufania do administracji publicznej oraz jej legitymizacji i skuteczności. Rozporządzenie w sprawie dostępu do dokumentów odnosi się do wszystkich dokumentów będących w posiadaniu Rady, Komisji oraz Parlamentu Europejskiego. Oznacza to, co do zasady, że obywatele mają prawo do badania dokumentów lub części dokumentów, o ile informacje w nich zawarte nie są informacjami poufnymi. Prezydencja zamierza promować przejrzystość w UE w celu zakończenia negocjacji w sprawie rewizji Rozporządzenia w sprawie dostępu do dokumentów.

\section{Więcej dla pieniędzy}

Budżet UE powinien być dostosowany do bieżących potrzeb i przyszłych wyzwań. Wymaga to reform oraz zmiany priorytetów w odniesieniu do wspólnych wydatków. Prezydencja jest przygotowana do zainicjowania debaty w tej sprawie, gdy tylko zostanie przedstawiony raport Komisji z przeglądu budżetu. Dyskusje w sprawach takich jak przyszła polityka spójności będą kontynuowane w ramach przeglądu budżetu.

\section{Ważne spotkania:}

- Konferencja Ministerialna na temat Strategii UE dla regionu Morza Bałtyckiego oraz strategii makroregionów, Sztokholm, 17-18 września.

- Wsparcie lokalne i regionalne dla Strategii Lizbońskiej, Goeteborg, 10-11 listopada.

- Konferencja wysokiego szczebla na temat równości płci, wzrostu gospodarczego i zatrudnienia, Sztokholm, 15-16 października.

- Konferencja na temat Polityki Spójności i Rozwoju Terytorialnego, Kiruna, 10-11 grudnia. 


\section{UE jako aktor globalny \\ GAERC-Stosunki zewnętrzne}

UE odgrywa obecnie bardzo istotną rolę w promowaniu pokoju, demokracji, praw człowieka i rozwoju w różnych częściach świata. Dla osiągnięcia sukcesu przez prezydencję niezmiernie istotne będą gotowość do radzenie sobie z nieprzewidzianymi sytuacjami i koordynowanie działań UE w sytuacjach kryzysowych. Ważne jest stosowanie wszystkich instrumentów polityki, od operacji zarządzania w obliczu kryzysu cywilnego oraz militarnego po dialog i dyplomację w ramach wspólnej polityki zagranicznej i bezpieczeństwa a inicjatyw polityki handlowej i rozwoju. Celem starań podejmowanych podczas prezydencji jest praca nad skuteczną i spójną polityką zewnętrzną w celu wzmocnienia UE jako globalnego aktora.

\section{Stosunki z krajami sąsiednimi}

Priorytetową kwestią będzie praca nad rozwojem Europejskiej Polityki Sąsiedztwa. Szczególna uwaga zostanie poświęcona wdrożeniu Partnerstwa Wschodniego. Celem Partnerstwa Wschodniego jest wzmacnianie i pogłębianie stosunków UE z sześcioma sąsiadami na wschodzie, Armenią, Azerbejdżanem, Białorusią, Gruzją, Mołdawią i Ukrainą oraz promowanie integracji tych krajów z UE w ważnych obszarach takich jak handel, migracja czy prawodawstwo. Prezydencja zamierza pracować nad zagwarantowaniem, aby wdrożenie Partnerstwa Wschodniego nabrało rozmachu i zostało skonsolidowane poprzez, między innymi, nową wielostronną współpracę, negocjacje w sprawie porozumień o stowarzyszeniu i wolnym handlu oraz kroki służące ułatwieniu mobilności osób. Negocjacje pomiędzy UE a Ukrainą w sprawie porozumienia o stowarzyszeniu, włączając kwestie wolnego handlu, będą miały priorytetowe znaczenie i będą stanowić ważną część planowanego szczytu. Prezydencja będzie również pracować nad pogłębieniem współpracy z sąsiadami UE w regionie Morza Śródziemnego, zarówno poprzez zaangażowanie w negocjacje UE z tymi krajami jak i w ramach Unii dla Śródziemnomorza. UE jako globalny aktor zostanie również wzmocniona poprzez postępy w procesie rozszerzania i ma znaczący interes strategiczny w rozwiązaniu kwestii Cypru. Ważną rolę będzie odgrywać kwestia Bałkanów Zachodnich przy skoncentrowaniu się na procesie integracji tych krajów z UE. Kluczowe znaczenie ma wzmocnienie sił dla reformy politycznej w Bośni i Hercegowinie. Prezydencja będzie pracować nad wzmocnieniem procesu reform w Kosowie i stosunków tego kraju z UE. Prezydencja będzie pracować również nad postępami w kwestiach dotyczących liberalizacji systemu wizowego dla obywateli regionu Bałkanów Zachodnich oraz ułatwień wizowych, mając na celu w długim okresie liberalizację systemu wizowego, dla obywateli krajów objętych Partnerstwem Wschodnim. Ważne ze strategicznego punktu widzenia są stosunki z Rosją. Szczyt z udziałem UE i Rosji jest zaplanowany w Sztokholmie. Jego założeniem jest kompleksowy i otwarty dialog oraz postęp w negocjacjach w sprawie nowego, szerokiego porozumienia. Ważna jest również kontynuacja dialogu w sprawie praw człowieka, wspólnego sąsiedztwa i zamrożonych konfliktów. 


\section{Wzmocniona wspólpraca i rola polityczna w świecie}

Wzmocnienie współpracy transatlantyckiej jest zagadnieniem mającym wielkie znaczenie strategiczne, nie tylko dla starań podejmowanych w celu osiagnięcia zrównoważonej globalizacji. Należy wykorzystać nową perspektywę pogłębienia współpracy z nową administracją w USA. Prezydencja będzie pracować nad rozwojem i pogłębianiem współpracy politycznej i gospodarczej, nie tylko w obszarach klimatu i energii oraz pokoju i bezpieczeństwa, lecz również w obszarze rynku transatlantyckiego bez barier handlowych. Na okres trwania prezydencji zaplanowany został szczyt z udziałem UE i USA. Podczas szczytu zaplanowanego w Sztokholmie szczególna uwaga zostanie poświęcona stosunkom pomiędzy UE a Brazylią. Wzmocniona i pogłębiona zostanie współpraca UE z krajami azjatyckimi. Zaplanowane są szczyty w Chinach i Indiach. Istotne znaczenie będą miały negocjacje w sprawie nowego porozumienia ramowego z Chinami oraz porozumienie w sprawie wolnego handlu i inwestycji z Indiami. UE przyjęła na siebie rosnącą odpowiedzialność jako aktor globalny. Można to zaobserwować na przykład w dialogu prowadzonym z Afganistanem i w operacjach tam prowadzonych zajmujących wysokie miejsce w agendzie UE, jak również w stosunkach z Pakistanem. Niezmiernie ważne jest by UE dalej wzmacniała i konsolidowała swoje zaangażowanie wobec tych krajów, włączając perspektywę regionalną. Priorytetowo zostanie potraktowana sytuacja na Środkowym Wschodzie oraz czynna rola UE w staraniach na rzecz pokoju. Praca nad dwupaństwowym rozwiązaniem - z państwem Palestyna i państwem Izrael egzystującymi ze sobą w pokoju - i szacunkiem dla zobowiązań wynikających z prawa międzynarodowego są sprawami pierwszorzędnymi. Szczególnej uwagi wymagać będzie Iran, nie tylko w odniesieniu do kwestii nuklearnej. Konieczny jest również wysoki poziom gotowości do zarządzania kryzysowego w związku z konfliktami w Afryce. Wdrożenie Wspólnej Strategii UE-Afryka również stanowi ważną kwestię. Zaplanowany został szczyt UE-Południowa Afryka.

Prezydencja zamierza prowadzić prace w kierunku osiągnięcia postępów w negocjacjach w sprawie porozumień o partnerstwie gospodarczym z wieloma krajami rozwijającymi się w Afryce, na Karaibach i w regionie Pacyfiku.

Prawo międzynarodowe, prawa człowieka, demokracja oraz zasady państwa prawa powinny przenikać prace w ramach wspólnej polityki zagranicznej i bezpieczeństwa UE, włączając dialog z krajami trzecimi oraz kwestie budowy pokoju przy współpracy UE z ONZ, OBWE oraz Radą Europy, a także politykę rozwoju UE. Prezydencja będzie również pracować nad większą widocznością polityki UE w zakresie praw człowieka.

Ostatnimi laty współpraca UE i jej rola w procesie rozbrojenia i nierozprzestrzeniania broni jądrowej uległa wzrostowi i będzie wzmacniana poprzez kontynuację Strategii UE przeciw rozprzestrzenianiu broni masowego rażenia i czynne starania podejmowane na całym świecie przy współpracy z partnerami.

\section{Rozwój zdolności zarządzania kryzysowego UE}

Rozwój zdolności zarządzania kryzysowego UE jest ważną częścią celu, którym jest wzmocnienie pozycji UE jako globalnego aktora. Celem jest poprawa zdolności UE do 
podejmowania działan $w$ sytuacjach kryzysowych i bardziej skuteczne przyczynienie się tym samym do pokoju i bezpieczeństwa. Prezydencja będzie pracować nad wzmocnieniem możliwości wykorzystania zdolności UE do cywilnego i militarnego zarządzania w sytuacjach kryzysowych, dla ciągłego rozwoju zdolności oraz dla bardziej skutecznej koordynacji pomiędzy instrumentami zarządzania kryzysowego UE. Konieczny jest rozwój europejskiej współpracy w kwestii zbrojeń w celu wzmocnienia europejskiej zdolności do zarządzania kryzysowego. Za kwestię priorytetową zostanie uznana współpraca pomiędzy UE a innymi organizacjami, włączając ONZ, OBWE, NATO oraz UA. Ponadto, kontynuowane będą prace nad prawami człowieka, bezpieczeństwem oraz rozwojem, równolegle z pracami UE nad mediacją i reformą sektora bezpieczeństwa. Prezydencja będzie kontynuować prace nad wdrożeniem rezolucji Rady Bezpieczeństwa ONZ w sprawie kobiet, pokoju i bezpieczeństwa. Kontynuacja toczących się działań zarządzania kryzysowego będzie ważną częścią pracy prezydencji. Będzie ona zwracać uwagę na dziesiątą rocznicę Europejskiej Polityki Bezpieczeństwa i Obrony.

\section{Zagadnienia rozwoju koncentrujące się na klimacie i demokracji}

Kluczowymi sprawami do rozwiązania w przyszłości są pomoc w zagwarantowaniu krajom rozwijającym się możliwości skutecznego zwalczania ubóstwa we wszystkich jego przejawach i sprostanie wyzwaniom, które pojawiają się wraz z nadejściem globalnego kryzysu gospodarczego oraz zmian klimatycznych. Wnioski zainicjowanej przez Szwecję Komisji ds. Zmian Klimatycznych i Rozwoju stanowią ważny wkład w prace w kierunku integracji adaptacji do zmian klimatycznych i do rozwoju współpracy, a także w kontekście spotkania w sprawie klimatu w Kopenhadze. Ważne jest wzmocnienie wsparcia UE dla budowania demokracji $w$ relacjach zewnętrznych w związku z faktem, że demokratyzacja przyczynia się do zmniejszania ubóstwa we wszystkich jego wymiarach. Zamierzeniem prezydencji jest stworzenie spójnych i jednolitych ram w celu uczynienia wsparcia UE dla procesu budowania demokracji na całym świecie bardziej efektywnym. Prezydencja będzie również pracować nad szczególnymi środkami służącymi uczynieniu europejskiej współpracy na rzecz rozwoju bardziej efektywną, aby zagwarantować wspólne działanie różnych obszarów polityki w celu przyczynienia się do zrównoważonego rozwoju globalnego, tj. spójności polityki rozwoju. Recesja gospodarcza uderza w najbiedniejsze kraje i jest przykładem kwestii, którą należy się zająć z poziomu kilku obszarów polityki.

\section{Zwiększony poziom wolnego handlu}

Wolny handel i otwartość promują wzrost, zatrudnienie i rozwój. Szybkie zakończenie negocjacji handlowych w Światowej Organizacji Handlu (Runda Dohijska) nabiera szczególnego znaczenia w kontekście obecnego kryzysu gospodarczego i tendencji protekcjonistycznych. Prezydencja będzie pracować również nad dokonaniem postępu i, o ile będzie to możliwe, zakończeniem toczących się negocjacji na temat porozumień w sprawie wolnego handlu z, na przykład, Koreą Pohudniowa, Indiami, Ukraina, Radą Współpracy Państw Zatoki Perskiej, Wspólnotą Andyjską oraz Ameryką Środkową. 
Ważną sprawą do rozpatrzenia w przyszłości jest sposób, w jaki wzrost i zagadnienia związane $z$ handlem mogą się wzajemnie wspierać. Prace będą się koncentrować na wzmocnieniu, a także rozwijaniu zewnętrznego wymiaru Strategii Lizbońskiej. Stosunki handlowe UE z krajami trzecimi powinny zostać również włączone jako wyraźny składnik następcy Strategii Lizbońskiej. Ponadto, prezydencja będzie pracować w celu zagwarantowania by polityka handlowa wzmacniała wysiłki stojące przed spotkaniem w sprawie klimatu w Kopenhadze. Należy zająć się zwiększoną potrzebą finansowania handlu ze środków publicznych wynikającą z kryzysu finansowego zapewniając zgodność z porozumieniami międzynarodowymi w tym zakresie. Ramy regulacyjne powinny zostać dostosowane w celu promowania rozpowszechniania technologii przyjaznej środowisku, w szczególności w krajach rozwijających się.

\section{Ważne spotkania:}

- Nieformalne Spotkanie Ministrów Spraw Zagranicznych (spotkanie „Gymnich”), Sztokholm, 4-5 września 2009 roku.

- Nieformalny obiad ministrów ds. handlu, Bruksela, 13 września.

- Nieformalne spotkanie ministrów ds. obrony, Goeteborg, 28-29 września.

- Europejskie Dni Rozwoju, Sztokholm, 22-24 października. Z udziałem ministrów ds. współpracy międzynarodowej na rzecz rozwoju itd.

- W ramach kompleksowej współpracy z krajami spoza UE i z organizacjami multilateralnymi będą miały miejsce liczne „spotkania krajów trzecich” w Brukseli, Nowym Jorku, Sztokholmie i w wielu innych miejscach.

\section{Odwrócenie postęów ekonomicznych ECOFIN - Rada do Spraw Gospodarczych i Finansowych}

Na kształt działań będzie mieć wpływ nieprzerwane zarządzanie kryzysem gospodarczym i finansowym, włączając pracę nad rozwiązaniem problemów na rynku finansowym oraz zajmowanie się kwestią recesji i wzrastającym bezrobociem. Celem prac jest odbudowanie zaufania do rynków finansowych i porządek w finansach publicznych oraz zwalczanie negatywnych wpływów kryzysu na wzrost i zatrudnienie.

\section{Kryzys gospodarczy i finansowy}

Od jesieni 2008 gospodarka europejska boryka się z wyzwaniami, jakie nie miały jeszcze miejsca we współczesnych czasach. Stan gospodarki globalnej uległ znacznemu pogorszeniu. Problemy światowych rynków finansowych utrudniły przedsiębiorstwom i gospodarstwom domowym pożyczanie pieniędzy. W połączeniu z ograniczoną podażą globalną i wysokim poziomem niepewności dało to efekt $w$ postaci największej recesji gospodarczej od lat 30-tych ubiegłego wieku. UE i jej Państwa Członkowskie prowadzą wspólne działania ukierunkowane na zwalczanie wszystkich aspektów kryzysu. Podjęto wiele działań w celu naprawy funkcjonowania systemu finansowego. W połączeniu ze środkami wdrożonymi przez Europejski Bank Centralny (EBC) i przez inne banki centralne pomogly one w częściowym przywróceniu zaufania do 
rynków finansowych. W grudniu 2008 roku, Rada Europejska przyjęła wspólny plan odbudowy ukierunkowany na złagodzenie wpływu kryzysu na wzrost i zatrudnienie w UE. W Państwach Członkowskich podjęto szereg środków, które, w połączeniu z faktem zezwolenia na wprowadzenie automatycznych stabilizatorów, zahamowały recesję gospodarczą. Głównym zadaniem prezydencji jest realizowanie prac UE w celu naprawy działania rynku finansowego i zwalczanie kryzysu gospodarczego. Wymaga to kontynuacji środków podejmowanych na rynku finansowym, włączając program gwarancji dla banków i zarządzania aktywami o obniżonej wartości. Wymaga to również kontynuowania i przeprowadzania oceny działań stymulujących podejmowanych przez UE i Państwa Członkowskie oraz inicjowania dyskusji na temat sposobu, w jaki można przywrócić równowagę w finansach publicznych. Priorytety dla działań w Radzie ECOFIN odzwierciedlają potrzebę szerokiego spectrum działań podejmowanych w tym obszarze polityki. Prezydencja jest gotowa do podejmowania dalszych inicjatyw koniecznych do zwalczania kryzysu gospodarczego i finansowego.

Kryzys ekonomiczny ma wymiar globalny. Jednym z ważnych forów służących prowadzeniu dyskusji i podejmowaniu decyzji w sprawie globalnych odpowiedzi na kryzys jest G-20 składające się z krajów, których udział w całkowitej produkcji globalnej wynosi $85 \%$. W drugiej połowie tego roku G-20 będzie zajmować się między innymi zagadnieniami dotyczącymi zwiększenia środków dla międzynarodowych instytucji finansowych. Prezydencja będzie pracować w Radzie ECOFIN w celu ustalenia wspólnego stanowiska UE przed spotkaniami G-20.

\section{Nadzór i regulacja rynków finansowych}

Doświadczenie wyniesione z kryzysu finansowego pokazało, że konieczna jest poprawa nadzoru oraz obowiązujących przepisów. Ważnym jest wzmocnienie obecnych ram regulacyjnych i stworzenie solidnego systemu ukierunkowanego na zapobieganie kryzysom pojawiającym się na rynkach finansowych w przyszłości. Proponowana nowa struktura nadzoru nad sektorem finansowym w UE jest ukierunkowana na zwiększenie szans na wykrywanie zagrożeń stabilności finansowej. Celem zmian jest, między innymi, poprawa koordynacji, współpraca i wymiana informacji między władzami zarówno na poziomie makro jak i mikro. Propozycje Komisji wymagają zwiększenia nadzoru obu z wyżej wymienionych poziomów. W tym kontekście proponowane jest ustanowienie wspólnego organu UE służącego kontroli makro-finansowej. Innym proponowanym elementem są trzy organy UE służące kontroli mikro-finansowej. Organom tym powierzone zostaną odpowiednie kompetencje i powinny one w szczególności gwarantować poprawę funkcjonowania kontroli transgranicznych grup finansowych w Europie. Zamierzeniem na czas prezydencji jest osiagnięcie porozumień politycznych w sprawie tych propozycji.

\section{Zrównoważone finanse publiczne w perspektywie dlugookresowej}

W czasach kryzysu szczególnie ważne jest odpowiednie wykorzystywanie środków i zachowanie porządku w finansach publicznych. Ważne jest również, aby działania wdrażane w celu równoważenia problemów krótkookresowych nie okazały się prze- 
ciwne do efektów pożądanych w dłuższej perspektywie. Równowaga i jakość finansów publicznych stanowią kwestię priorytetową. Dyscyplina budżetowa mająca na celu osiagnięcie stosownego porządku w finansach publicznych promuje zdrowy rozwój gospodarczy. W związku z tym ważne jest stosowanie Paktu Stabilizacji i Wzrostu w sposób poprawny i odpowiedzialny. Istnieje również potrzeba sformułowania strategii odnoszącej się do tego, w jaki sposób Państwa Członkowskie mogą odwrócić ich znaczne deficyty w finansach publicznych i w jaki sposób możemy przygotować się do sprostania wyzwaniom czekającym nas w przyszłości. Ponadto, musimy czynić postępy w staraniach odnoszących się do tego, w jaki sposób stawiamy czoła długookresowym wyzwaniom ekonomicznym takim jak starzejąca się populacja i finansowanie naszych systemów pomocy społecznej.

Polityka UE służąca promocji wzrostu i zatrudnienia w Państwach Członkowskich w perspektywie długookresowej została ujęta w Strategii Lizbońskiej. Ministrowie Finansów dokonają oceny kluczowych aspektów Strategii w obszarach im podlegających i omówią projekt tej polityki po 2010 roku. Prezydencja planuje również prowadzić wymianę doświadczeń i wiedzy dotyczącej praktycznej pracy budżetowej. Ma to na celu wzmocnienie procesu budżetowego w Państwach Członkowskich UE będącego częścią długookresowych wysiłków podejmowanych w celu poprawy jakości i stabilności finansów publicznych.

\section{Klimat}

Wysoce priorytetową kwestią jest pomoc w zagwarantowaniu kontynuacji negocjacji w sprawie klimatu. Decydującą kwestią jest finansowanie redukcji poziomów emisji i dostosowania do zmian klimatycznych. Instrumenty ekonomiczne takie jak podatek od emisji dwutlenku wegla i handel emisjami odgrywają kluczową rolę w staraniach podejmowanych w celu rozwiązania problemów w zakresie klimatu. W celu umożliwienia UE osiagnięcia jej celów polityki klimatycznej i energetycznej oraz przejścia na gospodarkę ekologiczną konieczne jest odpowiednie zaprojektowanie instrumentów ekonomicznych. W związku z tym, prezydencja będzie inicjować dyskusje odnoszące się do sposobu, w jaki możemy najskuteczniej wykorzystać instrumenty ekonomiczne takie jak te wymienione powyżej w polityce klimatycznej.

\section{Inne zagadnienia}

Jednym z ważnych zagadnień jest zagwarantowanie by Rada i Parlament Europejski zatwierdziły roczny budżet na rok 2010 . Kontynuowane będą również prace w celu stworzenia wewnętrznego rynku płatności w UE. Do innych ważnych zadań w agendzie należy opracowanie zharmonizowanych zasad fakturowania VAT, dobre zarządzanie $\mathrm{w}$ sprawach podatkowych ( $\mathrm{w}$ szczególności prace związane $\mathrm{z}$ opodatkowaniem dochodów z oszczędności) i zwalczanie oszustw podatkowych.

\section{Ważne spotkania:}

- Nieformalne spotkanie ECOFIN, Goeteborg, 1-2 października. W spotkaniu będą uczestniczyć także gubernatorzy Banków Centralnych Państw Członkowskich. 
- Nieformalne spotkanie Komitetu ds. Usług Finansowych (FSC), Sztokholm, 10 lipca.

- Nieformalne spotkanie ministrów odpowiedzialnych za e-administrację i konferencja e-administracja, Malmö, 18-20 listopada.

\section{Bardziej bezpieczna $i$ otwarta Europa Rada ds. Wymiaru Sprawiedliwości i Spraw Wewnętrznych (JHA)}

Dokonująca się w ostatnich latach globalizacja przyniosła zmianę i rozwój w pozytywnym kierunku ogółu społeczeństwa. Zwiększona mobilność wraz z nowymi technologiami dają olbrzymie możliwości, lecz przynoszą one także wyzwania. Aby skutecznie zajać się obecnymi przepływami migracyjnymi i promować pozytywne efekty migracji ważna jest sprawnie funkcjonująca współpraca transgraniczna. Współpraca transgraniczna, zarówno pomiędzy Państwami Członkowskimi UE, jak i pomiędzy UE a resztą świata jest konieczna również, by móc skutecznie zwalczać takie problemy jak przestępczość. Prezydencja przypada na ważny okres. Opracowany zostanie nowy strategiczny program działania (Program Sztokholmski) w celu ujęcia w nim całego obszaru polityki. Ważnym elementem przyszłego programu jest osiaggnięcie lepszej równowagi pomiędzy działaniami stojącymi na straży bezpieczeństwa i działaniami służącymi zachowaniu praw jednostki.

\section{Prawa obywateli}

Stworzenie większej pewności prawnej ma kluczowe znaczenie dla codziennego życia wielu obywateli. Wystapienie problemów cywilnoprawnych w związku z przemieszczeniem się osób w granicach UE lub w związku z posiadaniem przez nich mienia w innym Państwie Członkowskim może w praktyce zakłócać swobodne przemieszczanie się. Ważne jest rozpoczęcie negocjacji w sprawie regulacji dotyczących prawa spadkowego i testamentów. Regulacja obejmie zasady dotyczące europejskiego certyfikatu spadkowego jak i zasady dotyczące stosowanego prawa krajowego. Należy również dokonać przeglądu I rozporządzenia brukselskiego w sprawie uznawania i wykonywania orzeczeń sądowych $\mathrm{w}$ sprawach cywilnych. Jednym $\mathrm{z}$ ważnych projektów prawnych jest e-sprawiedliwość, w ramach którego pod koniec roku planowane jest otwarcie europejskiego portalu internetowego. Możliwe będzie wykorzystywanie portalu w celu wyszukiwania informacji na temat prawodawstwa i procesów sądowych w Państwach Członkowskich. Współpraca w UE w obszarze prawa karnego opiera się na zaufaniu Państw Członkowskich do systemów prawnych innych państw. Zasada wzajemnego uznawania i wykonywania wyroków i decyzji wydanych w innych państwach ma fundamentalne znaczenie. Działania służące budowaniu zaufania są konieczne dla skutecznego działania systemu. Na przykład, konieczne jest wzmocnienie ochrony praw osób podejrzanych o popełnienie przestępstwa. $\mathrm{W}$ drugim półroczy prowadzone będą negocjacje na temat minimalnych zasad odnoszących się do prawa osób podejrzanych i oskarżonych do bezpłatnego thumaczenia. Prezydencja będzie również prowadzić prace nad sprawami dotyczącymi wsparcia i udzielania informacji ofiarom przestępstw, niezależnie od tego, w którym Państwie Członkowskim przestępstwo zostało 
popełnione i negocjować wnioski Rady w sprawie skoordynowanej strategii wsparcia ofiar przestępstw.

\section{Walka z przestępczością}

Współpraca europejska odgrywa kluczowe znaczenie w zwalczaniu zorganizowanej przestępczości transgranicznej. Konieczny jest rozwój współpracy pomiędzy organami ścigania, włączając krajową policję, służbę celną i prokuratorów z jednej strony a europejską agencję ds. współpracy sądowniczej - Eurojust i Europejski Urząd Policyjny - Europol, z drugiej. Podstawą tej pracy jest bardziej skuteczna wymiana informacji, a prezydencja przedstawi propozycję strategii wymiany informacji. Przedstawiona zostanie również propozycja wprowadzenia obowiązkowej w całej UE akredytacji laboratoriów medycyny sądowej przetwarzających DNA i odciski palców. Kontrole graniczne prowadzone w Państwach Członkowskich są również ważnym narzędziem zwalczania przestępczości transgranicznej. Nowy System Informacyjny Schengen odegra kluczową rolę we współpracy międzynarodowej pomiędzy organami ścigania i w kontrolach granicznych, a prezydencja będzie traktować tę sprawę priorytetowo. W celu zwalczania przestępczości konieczny jest wzrost wymiany informacji pomiędzy władzami Państw Członkowskich UE. Prezydencja zamierza pracować nad tym, aby ta wymiana odpowiadała mechanizmom przetwarzającym informacje w sposób zgodny z prawem a jednocześnie chroniący prywatność jednostki. We współpracy z innymi Państwami Członkowskimi Szwecja podejmie inicjatywę propozycji przekazywania postępowań, co oznacza, że osoba podejrzana o popełnienie przestępstwa w jednym kraju może stanąć przed sądem w innym kraju. Powodem przekazywania postępowań jest fakt, że powinny one być prowadzone w miejscu najbardziej do tego odpowiednim, takim jak kraj zamieszkania podejrzanego lub kraj, w którym oskarżony jest już sądzony za inne przestępstwa. Prezydencja będzie prowadzić również prace w celu rozwoju wymiany wiedzy z zakresu przestępczości i metod służących jej zapobieganiu, szczególnie przestępczości, która wpływa na codzienne życie obywateli. Podjęte zostaną inicjatywy służące wzmocnieniu europejskiej sieci prewencji kryminalnej (EUCPN).

Do innych ważnych zagadnień do rozpatrzenia w drugiej połowie tego roku należy zacieśnienie regulacji UE w odniesieniu do wykorzystywania seksualnego dzieci i dziecięcej pornografii (włączając ,grooming”-działalność polegająca na seksualnym wykorzystywaniu dzieci przez osoby dorosłe, możliwym dzięki nawiązaniu kontaktu za pomocą technologii komunikacyjnych, zwłaszcza przez Internet i doprowadzaniu do kontaktów z nimi) oraz do zwalczania handlu ludźmi. Negocjowana będzie nowa decyzja ramowa odnosząca się do tych problemów. Ponadto, oczekuje się, że UE przyjmie plan działania w sprawie współpracy z krajami pochodzenia i tranzytu odnośnie handlu ludźmi. W Brukseli odbędzie się ministerialna konferencja na temat handlu ludźmi, w której będą uczestniczyć przedstawiciele Państw Członkowskich UE, Rosji, Ukrainy, Bałkanów Zachodnich i USA.

Ataki terrorystyczne przeprowadzane w ostatnich latach zarówno w Europie, jak i na całym świecie doprowadziły do zwiększenia współpracy w UE wymierzonej przeciwko terroryzmowi. Prezydencja będzie kontynuować te prace w oparciu o plan 
działania przyjęty przez UE. Nowe doświadczenia, wiedza i najlepsza praktyka z pewnością wywrą wpływ na tę współpracę. Przy opracowywaniu działań zapobiegawczych przeciwko radykalizacji i rekrutacji do ekstremistycznych grup stosujaccych przemoc można sięgać do udanych, wypracowanych na poziomie krajowym projektów.

\section{Zwiększona zdolność w zapobieganiu i zarządzaniu kryzysami i katastrofami}

Zdolność UE w zarządzaniu kryzysami i katastrofami uległa w ostatnich latach poprawie, lecz istnieje potrzeba rozwijania tej współpracy. Prezydencja będzie kontynuować tworzenie bezpieczniejszej Europy poprzez zmniejszanie zagrożenia kryzysami i katastrofami oraz poprzez dostosowywanie swojej zdolności zarządzania nimi. Podejmowane są działania w celu rozwoju prac Państw Członkowskich i UE nad zapobieganiem kryzysom i katastrofom. Wysiłki podejmowane w celu zwiększenia zdolności i współpracy w UE na rzecz zapobiegania i zarządzania poważnymi wypadkami spowodowanymi przez substancje chemiczne, biologiczne, radiologiczne i jądrowe stanowią część założeń w obszarze obrony cywilnej. Prezydencja omówi komunikat Komisji w sprawie działań służących zapobieganiu terroryzmowi w obszarze substancji chemicznych, biologicznych, radiologicznych i jądrowych w celu uzgodnienia dalszego działania.

\section{Wspólna polityka azylowa i migracyjna}

UE zdecydowała się wprowadzić wspólny system azylowy, który cechuje przejrzystość i pewność prawna. Zamierzeniem prezydencji jest przyczynienie się do dalszej harmonizacji prawa azylowego. W drugim półroczu renegocjowany będzie projekt dyrektywy majacej na celu stworzenie bardziej jednolitego sposobu przyjmowania azylantów w UE. Projekt zawiera zapisy o dostępie do rynku pracy dla ubiegających się o azyl. W celu utrzymania wiarygodności systemu azylowego, powinny istnieć przepisy, charakteryzujące się pewnością prawną odnośnie odsyłania osób, których wnioski o azyl zostały odrzucone, do kraju pochodzenia. Jednocześnie konieczne jest udzielanie wsparcia w przyjmowaniu uchodźców w regionach spoza UE. Istotnym przykładem wsparcia jest wspólny program przesiedleńczy UE. UE powinna podjać kroki, aby stawać się bardziej atrakcyjną dla migracji zarobkowej. Prace nad sformułowaniem wspólnych zasad będą kontynuowane $\mathrm{w}$ drugim półroczu. Powiązania pomiędzy migracją a rozwojem mają kluczowe znaczenie dla zrównoważonej i długookresowej polityki. Pozytywne wpływy migracji na rozwój zarówno w kraju docelowym jak i w kraju pochodzenia oraz skutki odczuwane przez samych migrantów będą promowane przy współpracy z krajami trzecimi. Będzie się to odbywać w ramach globalnego podejścia UE do migracji, w którym partnerstwo z krajami trzecimi jest ważnym narzędziem wdrażania tych wysiłków. Współpraca na poziomie UE jest również niezmiernie istotna w odniesieniu do polityki wizowej. Potrzebne są wspólne zasady służące ułatwieniu kontaktów pomiędzy ludźmi. Prezydencja pragnie pomóc zagwarantować sprawne wprowadzenie Systemu Informacji Wizowej (VIS) w grudniu 2009. System VIS ułatwi rozpatrywanie wniosków wizowych poprzez wprowadzenie wymogu odcisków palców i zdjęcia. Decyzja w sprawie wspólnej polityki wizowej zostanie podjęta w 2009 roku. 


\section{Wzmocnienie integracji poprzez wymianę wiedzy i doświadczeń}

W celu zagwarantowania praw jednostki i wykorzystania potencjału migracji potrzebna jest skuteczna polityka integracyjna. Punktem wyjściowym dla współpracy w UE w zakresie polityki integracyjnej jest zasada kompetencji krajowych Państw Członkowskich. Polityka integracyjna Państw Członkowskich powinna zostać wzmocniona poprzez skuteczną, zbudowaną na wspólnych, podstawowych zasadach integracji wymianę wiedzy i doświadczeń w Europie. Współpraca w UE ma przyczynić się do realizacji ambitnej polityki Państw Członkowskich zgodnej z wnioskami Rady w sprawie integracji z listopada 2008 r. Prezydencja zamierza prowadzić prace nad identyfikacja porównywalnych wskaźników na szczeblu europejskim w celu monitorowania wyników polityki integracyjnej.

\section{Ważne spotkania:}

- Nieformalne spotkanie Ministrów Wymiaru Sprawiedliwości i Spraw Wewnętrznych, Sztokholm, 15-17 lipca. Spotkanie będzie poświęcone dyskusji na temat nowego strategicznego programu działania dla współpracy w obszarze wymiaru sprawiedliwości i spraw wewnętrznych na lata 2010-2014.

- Konferencja: ,Justice in the EU - from the Citizen's Perspective” (Wymiar Sprawiedliwości w UE z perspektywy obywatela), Sztokholm, 22-23 lipca. Konferencja przyjrzy się dostępowi jednostek do wymiaru sprawiedliwości w UE.

- Konferencja: „Labour Migration and its Development Potential in the Age of Mobility" (Migracja zarobkowa i jej potencjał rozwojowy w erze mobilności), Malmö, 15-16 października.

- Konferencja ministerialna: „Towards EU Global Action against Trafficking in Human Beings" (W kierunku globalnego działania UE przeciwko handlowi ludźmi), Bruksela, 19-20 października. Obecni będą uczestnicy z UE, krajów EPS, Rosji, USA, etc.

- Konferencja: „Integration of New Arrivals - Incentives and Work in Focus” (Integracja przybyszów - wskazanie na znaczenie zachęt i pracy), Malmö 14-16 grudnia.

\section{Pelne zatrudnienie i dobry stan zdrowia}

\section{Rada ds. Zatrudnienia, Polityki Spolecznej, Zdrowia i Spraw Konsumenckich (EPSCO)}

Pełne zatrudnienie zarówno kobiet jak i mężczyzn oraz zredukowane wykluczenie poprzez trwałe reformy strukturalne będzie stanowić przedmiot prac. Dobry stan zdrowia jest kluczową kwestią zarówno ze względów ekonomicznych jak i społecznych. Spełnienie tych celów jest konieczne, aby UE mogła stawiać czoła wyzwaniom krótkookresowym w postaci wzrastającego bezrobocia i dhugookresowym takim jak globalizacja i starzejąca się populacja UE. Te względy będą wyznaczać kierunek prac prezydencji w obszarze rynku pracy, polityki społecznej, opieki zdrowotnej i równości płci. W kierunku pełnego zatrudnienia i bardziej integrujących społecznie rynków pracy. Praca 
stanowi najważniejszą podstawę dobrobytu ekonomicznego i społecznego zarówno dla jednostek jak i ogółu społeczeństwa. W perspektywie krótkookresowej kluczowe są działania służące zwiększaniu zatrudnienia. W perspektywie dhugookresowej konieczne jest wykorzystanie potencjału zasobów ludzkich całej UE i zapewnienie zatrudnienia większej liczbie osób. UE nie stać na to, aby ludzie pozostawali poza rynkiem pracy. Konieczne jest zbudowanie w Europie stabilnych fundamentów w celu konsolidacji rynków pracy i systemów zabezpieczenia społecznego. W obecnej sytuacji gospodarczej nie możemy krótkookresowo łagodzić skutków rosnącego bezrobocia poprzez zamykanie ludzi w systemie, który pociagga za sobą trwałe wykluczenie. Prezydencja będzie pracować nad znalezieniem rozwiązań, które złagodzą negatywne skutki niskiego poziomu wzrostu zatrudnienia i, które umożliwią przeprowadzanie ciagłych reform służących stworzeniu silniejszych i bardziej integrujących społecznie rynków pracy. Czynna polityka w zakresie rynku pracy i czynna polityka w zakresie ubezpieczeń społecznych stanowią ważny element tego procesu. W drugim półroczu prezydencja będzie dążyć do zagwarantowania spójnego i odpowiedzialnego działania UE w celu ochrony zatrudnienia i systemu opieki społecznej Europy w długoterminowej perspektywie. Prezydencja będzie w swoich pracach dążyć do celu pelnego zatrudnienia i bardziej integrujących społecznie rynków pracy w obszarze EPSCO. Celem jest przyjęcie wniosków w sprawie nowej strategii UE na rzecz wzrostu gospodarczego i zatrudnienia na następne dziesięć lat (tj. następna Strategia Lizbońska) przed szczytem Rady Europejskiej.

\section{Promowanie dobrego stanu zdrowia}

Dobry stan zdrowia obywateli UE jest niezmiernie ważny. Konieczne są działania zapobiegawcze. Negocjacje na temat dyrektywy o mobilności pacjentów, której celem jest zwiększenie możliwości pacjentów na poszukiwanie i otrzymywanie opieki zdrowotnej i dentystycznej w innym kraju UE, stanowią ważny priorytet na drugie półrocze. Innymi ważnymi zagadnieniami do omówienia w okresie prezydencji są warunki refundacji kosztów transgranicznej opieki medycznej oraz obszary przyszłej współpracy pomiędzy Państwami Członkowskimi w zakresie opieki zdrowotnej. Inną ważną sprawą dla pacjentów jest wzmocnienie wspólpracy w UE w zakresie e-zdrowia. UE musi być gotowa radzić sobie z obecnymi wyzwaniami zdrowotnymi. Jednym $\mathrm{z}$ takich wyzwań jest odporność na antybiotyki. Problem bakterii, które nie mogajuż być leczone antybiotykami narasta na całym świecie. Bez dostępu do skutecznych antybiotyków powszechne choroby mogą stać się śmiertelnym zagrożeniem. Ambicją prezydencji jest podjęcie decyzji w sprawie innowacyjnych sposobów zapewniających rozwój nowych antybiotyków. Podczas prezydencji konieczne będzie zajęcie się problemem spowodowanym przez wybuch grypy A (H1N1). Odbędzie się konferencja z udziałem ekspertów, podczas której eksperci UE w dziedzinie chorób zakaźnych omówią swoje doświadczenia i potrzebę podejmowania dalszych działań. Kolejnym wyzwaniem są fałszywe leki. Prezydencja będzie dążyć do osiągnięcia postępów w odniesieniu do pakietu farmaceutycznego, co obejmuje środki czujności farmakologicznej. Kolejnym zagadnieniem jest wdrożenie unijnej strategii alkoholowej. Komisja ma przedstawić pierwszy raport z postępów w sprawie wdrażania strategii na poziomie krajowym i eu- 
ropejskim. Ambicją jest ustanowienie długookresowych działań zapobiegawczych szkodom wyrządzonym przez alkohol.

\section{Zdrowsze i godne starzenie się}

Rosnący odsetek osób starszych jest wyzwaniem, lecz jednocześnie możliwością dla Państw Członkowskich. Celem prezydencji jest zwiększenie szans osób starszych w UE na starzenie się z godnością i w zdrowiu. Aby to osiągnąć, ważne jest zagwarantowanie tego, aby osoby pracujące nad sprawami związanymi ze zdrowiem i opieką społeczną lepiej ze sobą współpracowały i koncentrowały się na osobach starszych. Prezydencja pragnie znaleźć rozwiązania koordynacyjne i kooperacyjne oraz podkreślić znaczenie dobrych praktyk w różnych Państwach Członkowskich UE. Prezydencja pragnie poprzez tę inicjatywę dodać do agendy UE zagadnienia dotyczące osób starszych.

\section{Zwiększenie równości płci i wzmocniona ochrona przeciwko dyskryminacji}

W celu zwiększenia wzrostu i rozwoju, UE musi lepiej wykorzystywać potencjał zarówno kobiet jak i mężczyzn. Praca ministrów ds. równości płci będzie ukierunkowana na znaczenie równości płci dla rozwoju gospodarczego i zatrudnienia. Postępy w dziedzinie równości płci przyczynią się do rozwoju społeczeństwa cechującego się spójnością społeczna, wysokim poziomem zatrudnienia i zrównoważonym wzrostem gospodarczym. Do innych ważnych kwestii należą inicjatywy ukierunkowane na zwalczanie przemocy stosowanej przez mężczyzn wobec kobiet i kontynuacja planu działania ONZ na rzecz równości płci, Pekińska Platforma Działania. Prezydencja przedstawi sprawozdanie z rozwoju obszarów objętych Pekińską Platformą w ciągu ostatnich pięciu lat w Państwach Członkowskich UE. Prezydencja będzie pracować również nad podjęciem decyzji w kwestii projektów dyrektyw, które stworzą większe szanse na pogodzenie pracy zawodowej z życiem rodzinnym i zapewnią zwiększoną ochronę zdrowia i bezpieczeństwa: równe traktowanie samozatrudnionych kobiet i mężczyzn oraz działania służące poprawie zdrowia i bezpieczeństwa w miejscu pracy dla pracownic ciężarnych, pracownic, które niedawno urodziły dzieci lub karmiących piersią. Prace nad zwalczaniem wszelkich form dyskryminacji mają priorytetowe znaczenie. Prezydencja będzie prowadzić prace w celu zagwarantowania podjęcia decyzji w odniesieniu do dyrektywy w sprawie równego traktowania osób niezależnie od wyznania lub poglądów, upośledzenia, wieku lub orientacji seksualnej.

\section{Ważne spotkania:}

- Nieformalne spotkanie ministerialne, Jönköping, 6-9 lipca. Pierwsza część spotkania, w dniach 6-7 lipca, będzie poświęcona alkoholowi i zdrowiu, odporności na antybiotyki oraz e-zdrowiu. Druga część spotkania, w dniach 8-9 lipca, będzie się koncentrować na kwestii ograniczania wykluczenia.

- Konferencja: „Healthy and Dignified Ageing” (Zdrowe i godne starzenie się) Solna/Sztokholm, 15-16 września. 
- Konferencja z udziałem ekspertów na temat odporności na antybiotyki, Sztokholm, 17 września.

- Konferencja z udziałem ekspertów na temat alkoholu, Sztokholm, 21-22 września.

- Ósmy Europejski Okrągły Stół w sprawie ubóstwa i wykluczenia społecznego, Sztokholm, 15-16 października.

- Konferencja wysokiego szczebla w sprawie włączenia do rynku pracy, Sztokholm, 26-27 października.

- Konferencja wysokiego szczebla w sprawie znaczenia równości płci dla wzrostu gospodarczego i zatrudnienia, Sztokholm, 15-16 października.

- Szczyt Równości, 16-17 listopada.

\section{Konkurencyjna Europa Rada ds. Konkurencyjności}

Europa ma niezwykłą szansę na objęcie przywództwa w rozwoju w kierunku długookresowego zrównoważonego wzrostu poprzez dostosowanie do ekoefektywnej gospodarki. Wymogami wstępnymi są sprawnie funkcjonujący Jednolity Rynek cechujący się otwartością, dobrymi warunkami prowadzenia działalności gospodarczej, szczególnie dla małych i średnich przedsiębiorstw, zmniejszonymi barierami administracyjnymi, wspólną ochroną konsumentów i wolnym handlem. Zasoby wykorzystywane na badania i innowacje muszą zachowywać wysoką jakość i być wykorzystywane bardziej efektywnie, aby w większym stopniu przyczyniać się do wzmacniania konkurencyjności Europy. Przyszła strategia zrównoważonego wzrostu i zatrudnienia powinna być budowana w oparciu o te przesłanki i wraz z globalnym porozumieniem klimatycznym w Kopenhadze stanowić podstawę dla zrównoważonego wzrostu gospodarczego na równych warunkach.

\section{Uzdrowienie gospodarki i przejście na ekoefektywną gospodarkę}

W drugiej połowie bieżącego roku kontynuowane będzie wdrażanie planu naprawy gospodarczej. Celem planu jest zwiększenie popytu i ułatwienie inwestycji długoterminowych przy położeniu nacisku na długotrwały proces przechodzenia na ekoefektywną gospodarkę i na wzmocniony Jednolity Rynek. Ułatwienia dla nowych i rozwijających się gałęzi przemysłu utworzą nowe miejsca pracy i przyczynią się do osiągnięcia przez UE jej celów klimatycznych.

\section{Przyszla długotrwala strategia wzrostu}

Rada ds. Konkurencyjności wniesie wkład do dyskusji na temat następnej strategii lizbońskiej na lata 2010-2020. Jako ważne czynniki w tej dyskusji, prezydencja będzie szczególnie podkreślać przejście na ekoefektywną gospodarkę, wzmocniony rynek wewnętrzny oraz wymiar zewnętrzny. Gospodarka potrzebuje stabilnego, dhugookresowego podejścia strategii lizbońskiej. Rada ds. Konkurencyjności ma do odegrania kluczową rolę przywódczą w przechodzeniu na ekoefektywną gospodarkę w ścisłej współpracy z Radą ds. Energii i Środowiska Naturalnego i innymi konfiguracjami Rady. 


\section{Sprawnie funkcjonujący Jednolity Rynek}

Rynek wewnętrzny stanowi podstawę dla współpracy w UE. Wspólny rynek stwarza warunki dla wzrostu i zatrudnienia, i stanowi model dla całego świata. Rada ds. Konkurencyjności będzie kontynuować prace nad wzmocnieniem Jednolitego Rynku. W celu realizacji możliwości obywateli UE i przedsiębiorców ważne jest, aby współpraca pomiędzy Państwami Członkowskimi, władzami i instytucjami przebiegała sprawnie. Celem dla wszystkich powinno być znajomość, rozumienie, stosowanie i egzekwowanie zasad Jednolitego Rynku. Jednym z zagadnień, które będą uznane za priorytetowe jest oczekiwane zalecenie Komisji w sprawie partnerstwa z Państwami Członkowskimi dla wdrażania Jednolitego Rynku. Celem prac jest przyjęcie wniosków Rady w sprawie zalecenia obejmującego wszystkie Państwa Członkowskie i lepsza realizacja założeń Jednolitego Rynku poprzez współpracę, edukację i informacje. Wnioski moga pomóc ułatwić wzrost gospodarczy i zatrudnienie oraz skutkować większą świadomością swoich praw wśród przedsiębiorstw i konsumentów. Ważne są korzystne warunki stwarzane dla konkurencji, a liberalizacja regulacji odnoszących się do pomocy państwa powinna być jedynie tymczasowym działaniem. Prezydencja będzie dążyć do poczynienia możliwie największych postępów w negocjacjach w sprawie patentu wspólnotowego i Europejskiego Sądu Patentowego. Stworzenie ekonomicznie opłacalnego patentu wspólnotowego i systemu rozstrzygania sporów patentowych ma istotne znaczenie dla klimatu dla innowacji w Europie, a tym samym dla konkurencyjności UE. Skuteczna ochrona praw własności intelektualnej ma kluczowe znaczenie dla jak najlepszego wykorzystania przez UE istniejącej zdolności innowacyjnej. Dyrektywa usługowa zostanie wdrożona najpóźniej do grudnia. W celu ułatwienia swobody świadczenia usług, Państwa Członkowskie muszą pozbywać się niepotrzebnej biurokracji, upraszczać administrację i wzmacniać prawa konsumentów. Dla konsumentów dyrektywa o swobodzie świadczenia usług oznacza większe możliwości porównywania usług świadczonych w innych krajach i ochronę przeciwko dyskryminacji ze względu na narodowość lub miejsce zamieszkania. Aby osiągnąć możliwie największy wpływ na wzrost sektora usług, wszystkie Państwa Członkowskie powinny wymieniać swoje doświadczenia w ramach potencjału, jaki proponuje dyrektywa usługowa. Prezydencja będzie pracować nad osiągnięciem porozumienia dotyczącego projektu dyrektywy w sprawie praw konsumentów. Zharmonizowana ochrona konsumenta pomoże zwiększyć zaufanie konsumentów i przedsiębiorstw do handlu transgranicznego, przynosząc w efekcie większą konkurencyjność, większy wybór i niższe ceny.

\section{Poprawa warunków prowadzenia dzialalności gospodarczej}

Do jednych z głównych zadań należy ułatwienie codziennego prowadzenia działalności przez spółki, zapewniając w ten sposób podstawy istnienia długotrwałego i konkurencyjnego sektora przedsiębiorstw. Lepsze regulacje i ograniczenie obciążeń administracyjnych, lepszy dostęp do funduszy dla małych i średnich przedsiębiorstw oraz zachęcanie ich do uczestnictwa w procesie zamówień publicznych, ułatwianie zakładania i prowadzenia działalności gospodarczej przez kobiety, promowanie innowacji i wykorzystywanie potencjału towarzyszącego przejściu na ekoefektywną gospodarkę to decydujące 
czynniki, dzięki którym UE będzie mogła wyjść z obecnej sytuacji ekonomicznej. Ma to również znaczenie dla generowania długookresowego wzrostu i dalszego stosowania równego pola gry w odniesieniu do przedsiębiorczości w UE. Europa musi wspierać wydobywanie własnych surowców. Poprawiając kryteria środowiskowe w zamówieniach publicznych przyczynimy się do zwiększenia wzrostu gospodarczego.

\section{Konkurencyjna europejska przestrzeń badań i innowacji}

Prace będą się koncentrować na sposobie, w jaki UE ma wykorzystywać zasoby badawcze w bardziej efektywny sposób. Celem jest uzgodnienie tego, jakie zasoby powinny być wykorzystywane i sposobu lepszej koordynacji i zarządzania tymi inwestycjami. Jednym $\mathrm{z}$ ważnych zagadnień jest projekt wspólnych inicjatyw na poziomie europejskim, włączając Program Ramowy UE dla Badań Naukowych. Prezydencja będzie priorytetowo traktować dyskusję na temat sposobu, w jaki europejskie badania naukowe mogą najlepiej sprostać przyszłym wymaganiom w takich obszarach jak zdrowie, energia oraz klimat. Rozwój rynku wewnętrznego dla badań i innowacji, tj. europejskiej przestrzeni badawczej, który wymaga zarówno krajowych jak i wspólnych inicjatyw, również zajmuje wysoką pozycję w agendzie. Prezydencja będzie kontynuować rozpoczęte prace i dążyć do zaproponowania mechanizmów zarządzania dla efektywnego wykorzystania tych zasobów i lepszej współpracy pomiędzy obszarami polityki, np. w kontekście trójkąta wiedzy. Innowacje będą niezmiernie ważne w przekształcaniu europejskiego sektora przedsiębiorstw tak, by stał się on bardziej zrównoważony i wykorzystywał wymogi zrównoważonej produkcji i konsumpcji w celu wzmocnienia konkurencyjności. Prezydencja wniesie wkład do Europejskiego Planu Działania dla Innowacji, który łączy się z europejską przestrzenią badawczą.

\section{Ważne spotkania:}

- Nieformalne spotkanie ministrów, Umea, 14-16 października. Spotkanie będzie się koncentrować na zagadnieniach na przyszłość, takich jak stała wydajność rynku wewnętrznego otwartego na zewnątrz, przejście na ekoefektywną gospodarkę oraz sposoby sprostania przyszłym wyzwaniom badawczym.

- Konferencja: „New Worlds, New Solutions - Research and Innovation as a Basis for Developing Europe in a Global Context" Nowe światy, nowe rozwiązania - badania i innowacje jako podstawa rozwijającej się Europy w kontekście globalnym), Lund, 6-8 lipca.

- Konferencja: „The Knowledge Triangle Shaping the Future of Europe” (Trójkąt wiedzy kształtujący przyszłość Europy), Göteborg, 31 sierpnia-2 września.

- Konferencja: „Safe Products - At the Core of the EU Single Market” Bezpieczne produkty - istotą Jednolitego Rynku UE), Solna/Sztokholm, 11 września.

- Konferencja: „From the Charter for Small Enterprises to the Small Business Act” (Od Karty Małych Przedsiębiorców do ustawy o małych przedsiębiorstwach), Upplands Väsby/Sztokholm, 4-6 października. Specjalne warsztaty zostaną poświęcone kwestii przedsiębiorczości kobiet. Do pozostałych tematów warsztatów należeć będą ekologiczne innowacje, zielone zamówienia publiczne oraz działania ukierunkowane na oszczędność energii w małych i średnich spółkach. 
- Europejski Dzień Konkurencyjności, Upplands Väsby/Sztokholm, 7 października.

- Konferencja: „An Eco-efficient Economy - Towards Innovative and Sustainable Competitiveness" (Gospodarka ekologiczna - ku innowacyjnej i zrównoważonej konkurencyjności), Linköping, 2-3 listopada.

- Konferencja: „Consumer Rights in the Internal Market” (Prawa konsumenta na rynku wewnętrznym), 4 listopada.

- International Regulatory Reform Conference (Międzynarodowa konferencja poświęcona reformie regulacyjnej), Sztokholm, 11-13 listopada. Konferencja będzie koncentrować się na różnych aspektach reformy regulacyjnej i lepszych uregulowań z perspektywy przedsiębiorstw.

- Konferencja: „The Enforcement of Intellectual Property Rights” (Wykonywanie prawa własności intelektualnej), Sztokholm, 15-16 grudnia.

\section{W kierunku ekoefektywnej gospodarki - transport, telekomunikacja i energia Rada ds. Transportu, Telekomunikacji i Energii (TTE)}

Przejście na ekoefektywną gospodarkę pozwoli sprostać wyzwaniom klimatycznym i wzmocnić konkurencyjność UE. W obszarze transportu, prezydencja będzie przypisywać priorytetowe znaczenie sformułowaniu polityki transportowej UE po roku 2010, logistyce przewozów towarowych oraz wdrażaniu nowych technologii. W obszarze technologii informatycznych/telekomunikacji, prace będą się koncentrować na wkładzie technologii informatycznych w zwiększanie konkurencyjności UE. Dzięki stosowaniu technologii informatycznych, Europa może stać się bardziej zrównoważona ekonomicznie, konkurencyjna i wydajna. W obszarze energii, kontynuowane będzie wdrażanie drugiego przeglądu strategii energetycznej, ze szczególnym naciskiem położonym na efektywność energetyczną.

\section{Polityka transportowa na przyszłość}

Globalizacja wymaga większej liczby nowych rozwiązań dla zrównoważonego transportu. Prezydencja będzie koncentrować swe prace na zrównoważonym i ekologicznym systemie transportowym. Europa potrzebuje spójnego, wydajnego systemu transportowego, w którym koordynowane są różne rodzaje transportu. Poprzez osiągnięcie lepszego wspólnego funkcjonowania różnych elementów systemu transportowego możliwe jest zmniejszenie skutków zmian klimatycznych. Prezydencja będzie traktować priorytetowo prace nad przyszłą polityką transportowa, które obejmują dyskusję na temat Transeuropejskiej Sieci Transportowej (TEN-T), zielone korytarze oraz bardziej efektywne wykorzystanie przestrzeni powietrznej. Do ważnych narzędzi należy poprawa logistyki i wprowadzenie nowych rozwiązań technologicznych, w związku z czym prezydencja będzie priorytetowo traktować wdrożenie ram dla opracowania inteligentnych systemów transportowych (ITS). Efektywna logistyka opiera się o konkurencyjną żegluge i koleje. Koleje i żegluga będą rozwijane poprzez propozycje dotyczące sieci kolei służących konkurencyjnemu przewozowi towarów oraz europejskiego obszaru transportu morskiego bez granic. Ministrowie transportu będą kontynuować prace jesienią. Czynione są postępy w sprawie uregulowania praw pasażera, a prezydencja bę- 
dzie dążyć do osiagnięcia porozumień w sprawie regulacji zarówno w kwestii pasażerów autobusów jak i statków. Prace nad Galileo, cywilnym europejskim systemem nawigacji satelitarnej przebiegają zgodnie z planem. W obszarze lotnictwa omówiona zostanie dyrektywa w sprawie opłat za ochronę lotnictwa.

\section{Telekomunikacja/technologia informacyjne oraz dostępne spoleczeństwo wiedzy}

Technologie informacyjne oraz łączność elektroniczna są ważnymi składnikami wzrostu gospodarczego i rosnącej konkurencyjności Europy. Technologie informacyjne są w dużym stopniu integralną częścią codziennego życia, zarówno jednostek jak i spółek, lecz ich potencjał nie jest w pełni wykorzystywany. Opracowywane mogą być nowe usługi, np. usługi promujące społeczeństwo bardziej zrównoważone ekologicznie. Technologie informacyjne stwarzają możliwości innowacji i zwiększonej konkurencyjności europejskiej. Prezydencja zamierza przyczynić się do tego, aby przyszła wspólna polityka UE koncentrowała się na społeczeństwie informacyjnym. UE potrzebuje nowoczesnych, perspektywicznych ram regulacyjnych dla łączności elektronicznej. Prezydencja będzie pracować nad zagwarantowaniem zatwierdzenia jesienią pakietu telekomunikacyjnego, czyli zweryfikowanych ram regulacyjnych dla łączności elektronicznej. Zakresy częstotliwości, które zostały uwolnione dla usług łączności innych niż TV, dywidendy cyfrowe, są dobrze dostosowane do ruchomych usług szerokopasmowych o adekwatnym zasięgu umożliwiającym dobrą łączność, szczególnie na obszarach słabo zaludnionych. Gdyby więcej krajów zarządzało swoimi dywidendami cyfrowymi w skoordynowany sposób, korzyści dla konsumentów byłyby olbrzymie.

\section{Skuteczna polityka energetyezna}

Zagadnienia związane z energią są nadal bardzo istotne, szczególnie w kontekście międzynarodowych negocjacji klimatycznych. Przejście na europejską ekoefektywną gospodarkę jest konieczne dla konkurencyjności, bezpieczeństwa energetycznego i środowiska naturalnego. Drugi przegląd strategii energetycznej oraz pakiet inicjatyw w sprawie bezpieczeństwa dostaw przedstawiony przez Komisję w listopadzie $2008 \mathrm{r}$. będą stanowić podstawę tych prac. Ministrowie odpowiedzialni za energię będą kontynuować prace na rzecz bezpieczeństwa energetycznego w UE oraz solidarnego planu działania. Jesienią nacisk położony zostanie na środkach efektywności energetycznej. Efektywność energetyczna ma kluczowe znaczenie, zarówno dla klimatu jak i bezpiecznych dostaw energii. Prezydencja zamierza prowadzić prace w celu zagwarantowania podjęcia decyzji odnośnie proponowanej zmiany dyrektywy w sprawie efektywności energetycznej budynków. Ministrowie energii omówią również i wniosą swój wkład w przygotowywany zrewidowany plan działania na rzecz efektywności energetycznej. Po tegorocznym kryzysie gazowym, Komisja wniosła propozycję w sprawie bezpieczeństwa dostaw, obejmującą zmianę do obecnie obowiązującej dyrektywy w sprawie bezpieczeństwa dostaw gazu. Prezydencja zamierza prowadzić prace w kierunku osiagnięcia wczesnego porozumienia pomiędzy Radą a Parlamentem Europejskim. Prezydencja przyjrzy się również oczekiwanemu komunikatowi w sprawie finansowania technologii niskoemisyjnych. Stosunki międzynarodowe UE oraz dialog w dziedzi- 
nie energii mają coraz większe znaczenie. Spodziewane są negocjacje w sprawie poszerzenia Wspólnoty Energetycznej o Mołdawię, Ukrainę oraz Turcję, a także w sprawie współpracy energetycznej pomiędzy UE a Nigerią. Istotny jest rozwój rynku energetycznego wokół Morza Bałtyckiego. Prace nad wdrożeniem planu działań związanych z połączeniami międzysystemowymi na rynku energii państw baltyckich będą kontynuowane. Głównym tematem podczas nieformalnego spotkania ministrów energii będzie przechodzenie na ekoefektywną gospodarkę, z podkreśleniem wydajnych systemów energetycznych.

\section{Ważne spotkania:}

- Nieformalne spotkanie ministrów energii, Are, 23-24 lipca.

- Nieformalny obiad roboczy z udziałem ministrów transportu, Sztokholm, 21 września, „EU Transport Policy after 2010 - The Future of Transport” (Polityka transportowa UE po roku 2010 - Przyszłość transportu).

- Konferencja wysokiego szczebla: „Effective Bioenergy” (Wydajna bioenergia), Sztokholm, 17-18 września.

- Spotkanie wysokiego szczebla: „Greater Use of Both New and Already Existing Technologies" (Większe wykorzystanie nowych i już istniejących technologii) w sprawie nowych technologii dla bezpiecznego, przyjaznego środowisku transportu drogowego, Göteborg, 26-27 października.

- Konferencja wysokiego szczebla: „Creating impact for an eUnion 2015” (Wywieranie wpływu na e-Unię 2015) na temat społeczeństwa informacyjnego w przyszłości, Visby, 10-11 listopada.

\section{Korzystanie z zasobów bez ich zużywania Rada ds. Rolnictwa i Rybolówstwa}

Rada ds. Rolnictwa i Rybołówstwa zajmuje się kwestiami związanymi z żywnością, zdrowiem zwierząt, rozwojem wsi, ważnymi kwestiami, które mają wpływ na codzienne życie obywateli UE. Prezydencja wyznacza trzy priorytety: „zrównoważone rybołówstwo”, ,żywność i klimat - globalne wyzwania” oraz „prawidłowa produkcja zwierzęca i zdrowe zwierzęta".

\section{Długookresowe zrównoważone rybołówstwo}

Ogólna koncepcja prezydencji dotycząca polityki rybołówstwa ma w założeniu stworzenie warunków korzystania z zasobów bez ich zużywania. Korzystanie z zasobów mórz musi być zrównoważone w skali długookresowej, pod względem gospodarczym, środowiskowym i społecznym. Obecna sytuacja zarówno stad ryb, jak i przemysłu rybnego pokazuje, że wspólnej polityce rybołówstwa nie udało się osiagnąć zamierzonych celów. Obecna sytuacja charakteryzuje się przetrzebionymi stadami ryb, niskim poziomem zrównoważenia ekologicznego i niską zyskownością. Każdego roku na jesieni Rada podejmuje decyzje w sprawie regulacji dotyczących rybołówstwa na następne 
lata, w tym kwot połowowych. Ambicją prezydencji jest ustanowienie na podstawie tej decyzji podstaw do zrównoważonego rybołówstwa. Kluczowym aspektem w osiagnięciu zrównoważenia jest zgodność z ramami regulacyjnymi. W tym celu, wymagany jest skuteczny system kontroli. Skuteczny system kontroli połowów zwiększa zaufanie do wspólnej polityki rybołówstwa i daje konsumentom poczucie pewności, że ryby łowione są zgodnie z prawem. Obecnie trwają negocjacje dotyczące nowej propozycji regulacji w zakresie kontroli połowów. Ambicją prezydencji jest zakończenie negocjacji jesienią, skupiając się na stosowności i wydajności kosztów. Oprócz kontroli połowów, rozpoczęty zostanie przegląd obecnie obowiązujących ram regulacyjnych wspólnej polityki rybołówstwa, który potrwa do końca 2012 roku. Ministrowie rybołówstwa nadal będą prowadzić rozmowy na temat przyszłych polityk rybołówstwa, w oparciu o zieloną księgę przedstawioną przez Komisję.

\section{Żywność i klimat - globalne wyzwania}

Globalizacja jest związana z wyższym stopniem wzajemnej zależności i tym samym z większą potrzebą transgranicznej współpracy politycznej. Dwa główne globalne wyzwania stojące przed rolnictwem dotyczą zarządzania wzajemnym wpływem rolnictwa i klimatu oraz zabezpieczenia globalnych dostaw żywności. Ministrowie rolnictwa będą omawiać kwestie związane z rolnictwem i klimatem podczas nieformalnych spotkań. Sektor rolnictwa jest ważnym uczestnikiem prac w zakresie zmian klimatycznych. Rolnictwo musi pomagać w ograniczaniu swojego wpływu na klimat i dostosować się do zmian klimatycznych. Jest to konieczne, aby poradzić sobie z przyszłymi zmianami klimatu i poprawić efektywność środowiskową i zasobów. Wytwarzanie zrównoważonej energii i środki dotyczące efektywności energetycznej są ważnymi aspektami tych starań. Zmiany klimatyczne mogą także doprowadzić do zmiany warunków produkcji rolnej, w wyniku czego moga, przykładowo, pojawić się nowe choroby roślin i zwierząt, jak również mogą zmienić się warunki wodne. Należy uwzględnić te ważne kwestie, aby zapewnić zrównoważone bezpieczeństwo żywnościowe.

Zagwarantowanie globalnego bezpieczeństwa żywnościowego przyszłym pokoleniom będzie wyzwaniem, szczególnie ze względu na fakt, że szacuje się, że do roku 2050 liczba ludności na świecie podwoi się. Organizacja Narodów Zjednoczonych do Spraw Wyżywienia i Rolnictwa (FAO) będzie odgrywać ważną rolę w osiągnięciu tego celu. Jesienią odbędzie się spotkanie najwyższego organu decyzyjnego FAO - Konferencji. Prezydencja będzie wypowiadać się w imieniu UE i dążyć do przyspieszenia prac FAO, w celu zabezpieczenia światowych zrównoważonych dostaw żywności. Bezpieczeństwo żywnościowe wciąż jest bardzo ważne. Istotne jest również umożliwienie konsumentom dokonywania świadomych wyborów żywności z uwagi na zdrowy styl życia. Prezydencja podejmie zatem działania umożliwiające Radzie i Parlamentowi Europejskiemu podejmowanie decyzji w sprawie nowej żywności. Unia Europejska od dawna stosuje regulacje dotyczące etykietowania żywności. Ważne jest, aby konsumenci we wszystkich państwach UE mogli dokonywać świadomych wyborów. Prezydencja podejmie działania zmierzające do osiagnięcia porozumienia w sprawie nowych regulacji dotyczących informacji na temat żywności dla konsumentów, które poprawią informacje dla konsumentów w zakresie wartości odżywczej żywności. 


\section{Prawidłowa produkcja zwierzęca i zdrowie zwierząt}

Prawidłowa produkcja zwierzęca jest istotna dla dobra zwierząt. Prawidłowa produkcja zwierzęca jest także kluczem do zdrowia publicznego, zaufania konsumentów i interesów producentów. Ważne jest także zapewnienie dobrostanu zwierząt. W przygotowaniu jest kilka propozycji nowych ustaw dotyczących dobrostanu zwierząt, jeśli chodzi o zwierzęta wykorzystywane do produkcji żywności i zwierzęta wykorzystywane do celów naukowych. Kwestie te są priorytetowe dla prezydencji. Prezydencja będzie również kontynuować prace nad strategią UE dotyczącą zdrowia zwierząt, „Lepiej zapobiegać niż leczyć", która będzie odgrywać ważną rolę dla przyszłego dobrostanu zwierząt w UE.

\section{Ważne spotkania:}

- Nieformalne spotkanie ministrów rolnictwa, Växjö, 13-15 września.

- Spotkanie dyrektorów generalnych ds. rybołówstwa, Ronneby, 2-3 lipca.

- Konferencja „Inland Water Brings Life into the Sea” (Wody śródlądowe ożywiaja morze), Lund, 21-23 września.

- Posiedzenie forum doradczego EFSA i spotkanie dyrektorów Europejskich Urzędów ds. Bezpieczeństwa Żywności, Sztokholm, 23-25 września.

- Spotkanie dyrektorów generalnych ds. leśnictwa, Göteborg, 30 września-1 października.

- Spotkanie dyrektorów generalnych ds. instytucji płatniczych, Visby, 7-9 października.

- „Delivering Animal Welfare Quality” (Zapewnianie jakości dobrostanu zwierząt), Uppsala, 8-9 października.

- Spotkanie głównych lekarzy weterynarii, Jönköping, 20-23 października.

- Konferencja „Rural Areas Shaping the Future” (Obszary wiejskie kształtujące przyszłość), Uppsala, 28-29 października.

- Konferencja „Climate-smart Food”, Lund, 21-23 listopada.

\section{Wiarygodna UE na rzecz środowiska naturalnego Rada ds. Srodowiska Naturalnego}

UE odgrywa kluczową rolę w rozwiązywaniu transgranicznych problemów dotyczących środowiska naturalnego i w podejmowaniu wzmożonych wysiłków globalnych na rzecz środowiska. Ambitna europejska polityka w zakresie środowiska naturalnego ma decydujące znaczenie dla globalnej zmiany. UE musi być siła, aktywnie działającą na rzecz zrównoważonego rozwoju na świecie. Prezydencja wzmocni unijną politykę w zakresie środowiska naturalnego i wykaże, że ambitna polityka w zakresie środowiska naturalnego jest warunkiem koniecznym dla długotrwałego zrównoważonego rozwoju. Jednoczenie krajów świata wokół ambitnego porozumienia w sprawie klimatu - Ramowa konwencja Narodów Zjednoczonych w sprawie zmian klimatu - jest istotą międzynarodowych działań na rzecz klimatu. Powiązany protokół z Kioto zawiera zobowiązania dotyczące ograniczenia emisji do końca 2012 roku. Na 
Konferencji Stron Konwencji Narodów Zjednoczonych w sprawie zmian klimatu, która odbędzie się w Kopenhadze w grudniu 2009 r. zostaną podjęte decyzje dotyczące nowych zobowiązań na okres po roku 2012. UE będzie odgrywać wiodącą rolę w ochronie klimatu. Zadaniem prezydencji wraz pozostałymi Państwami Członkowskimi UE i innymi stronami jest praca nad przyjęciem nowego porozumienia w sprawie klimatu w czasie międzynarodowych negocjacji klimatycznych w grudniu, w Kopenhadze. Porozumienie powinno obejmować wszystkie kraje świata, ograniczyć emisje, tak aby cel „dwóch stopni” był osiaggalny oraz stworzyć warunki dla zrównoważonego rozwoju gospodarczego.

\section{Ekoefektywna gospodarka daje przewagę konkurencyjną}

Jesienią ministrowie państw UE odpowiedzialni za środowisko naturalne, energię i konkurencję będą dyskutować na temat tego, w jaki sposób Europa może rozwinąć ekoefektywną gospodarkę. Zaangażowane i dynamiczne wysiłki na rzecz środowiska naturalnego dają przewagę konkurencyjną. Przejście na ekoefektywną gospodarkę oznacza dla UE szansę wyjścia z kryzysu gospodarczego i mogłoby przyczynić się do rozwoju długookresowej strategii dla Europy. Ministrowie środowiska naturalnego będą także zajmować się rozdziałem poświęconym środowisku naturalnemu w ramach wykonywania strategii zrównoważonego rozwoju UE. Szczególna uwaga zostanie poświęcona roli miast w kształtowaniu zrównoważonego globalnego rozwoju.

\section{Kluczowa rola bioróżnorodności}

Bioróżnorodność dotyczy bogactwa natury w ekosystemach, gatunkach i odmianach genetycznych. Bioróżnorodność jest potrzebna środowisku naturalnemu, aby mogło ono dostosować się do zmian siedliskowych, w szczególności do zmian wywołanych działalnością człowieka. Zagrożenia dla bioróżnorodności i tym samym dla zdolności samego środowiska do przetrwania są tak złożone jak zmyślna jest budowa ekosystemów. Konwencja Narodów Zjednoczonych o różnorodności biologicznej (CBD) jest globalnym porozumieniem w sprawie zachowania i zrównoważonego wykorzystania różnorodności biologicznej. Konferencja stron planowana na październik 2010 r. ma ocenić, czy na świecie udało się powstrzymać straty w bioróżnorodności i stworzyć długookresowy plan tych prac. Wiosną 2010 r. UE ma przygotować własną wizję. Prezydencja podejmie działania zmierzające do zapewnienia, że UE rozpocznie rozmowy na temat nowej globalnej wizji oraz do podkreślenia kluczowej roli ekosystemów dla dobrobytu ludzi. Prezydencja pragnie również zwrócić uwagę na pozytywne skutki ekonomiczne utrzymania bioróżnorodności, takie jak naturalna zdolność jezior do oczyszczania ścieków i koszty niepodejmowania inicjatyw.

\section{Wzmocniona polityka dotyeząca zaniedbanego środowiska morskiego}

Morza są z natury międzynarodowymi obszarami wymagającymi współpracy transgranicznej. Na środowisko morskie wpływają unijne polityki takich sektorów, jak rolnictwo, rybołówstwo, transport i przemysł. Emisje rolnictwa i systemów ściekowych 
prowadzą do eutrofizacji, a emisje z fabryk przemysłowych i oczyszczalni ścieków zanieczyszczają oceany chemikaliami. Szczególnie poważna jest sytuacja w Morzu Baltyckim. Kroki podejmowane do rozwiązania tych problemów będą omawiane przez ministrów środowiska naturalnego i innych w ramach Strategii UE dla regionu Morza Baltyckiego. Prezydencja aktywnie działa w zakresie objęcia regionu Morza Bałtyckiego specjalnym projektem pilotażowym z szybszą i bardziej rygorystyczną ochroną środowiska związaną z wprowadzaniem w życie dyrektyw morskich UE. Szczególna uwaga zostanie także poświęcona wdrożeniu wspólnej polityki morskiej UE oraz wymianie doświadczenia między różnymi przybrzeżnymi regionami UE.

\section{Inne ważne kwestie}

Globalne problemy związane z zanieczyszczeniem chemicznym od dawna są traktowane jako sprawy priorytetowe. Prezydencja będzie promować aktywną rolę UE w negocjacjach dotyczących globalnej konwencji w sprawie rtęci. Prezydencja będzie także aktywnie działać, aby doprowadzić do decyzji w sprawie dalszej eliminacji emisji substancji, które są silnymi gazami cieplarnianymi na spotkaniu stron Protokołu z Montrealu o substancjach zubażających warstwę ozonową. W programie obrad może również znaleźć się renegocjacja Protokołu z Gothenburga do konwencji w sprawie transgranicznego zanieczyszczenia powietrza na dalekie odległości. Renegocjacje doprowadzą do mniejszej emisji tlenku azotu, co korzystnie wpłynie zarówno na zdrowie ludzi, jak i na środowisko naturalne.

\section{Ważne spotkania:}

- Nieformalne spotkanie ministrów środowiska naturalnego, Are, 24-25 lipca.

- Konferencja wysokiego szczebla (Wizje dotyczące bioróżnorodności po roku 2010), Strömstad, 7-9 września.

- Konferencja wysokiego szczebla (Miasta europejskie a agenda w sprawie zmian klimatu na świecie), Sztokholm, 14-15 września.

- Konferencja Wody śródlądowe ożywiają morze, Lund, 21-23 września.

\section{Wysokie standardy promuja lepszy rozwój Rada ds. Edukacji, Mtodzieży i Kultury}

Wysokie standardy edukacji i badań, stworzenie odpowiednich możliwości dla kreatywności i innowacji oraz dobrych warunków życiowych dla młodych ludzi są szczególnie ważne dla rozwoju jednostki i zrównoważonego rozwoju w UE. W związku z powyższym, prezydencja skoncentruje swoje działania na następujących kwestiach: dalszy rozwój europejskiej współpracy w zakresie edukacji - poprawa współpracy między edukacja, badaniami i innowacją; zwrócenie uwagi na warunki emigrantów osiagania sukcesu w społeczeństwie poprzez odpowiednie kształcenie; zachęcanie i wspieranie dostępu dzieci i młodych ludzi do kultury i mediów oraz wspieranie ich możliwości do rozwijania własnej kreatywności; osiagnięcie porozumienia w sprawie kierunku przyszłej współpracy w obszarze młodzieży. 


\section{Edukacja - wspólpraca, modernizacja i integracja}

Europejska współpraca w dziedzinie edukacji w znacznym stopniu dotyczy omówienia rozwiązań wspólnych wyzwań i problemów, jak również wymiany informacji i dobrych praktyk. Celem jest podniesienie standardów edukacji i zapewnienie uczniom, studentom i nauczycielom dobrych warunków pracy. W ramach priorytetów „Edukacja i szkolenie 2020" prezydencja za najważniejsze uznaje kwestie związane z rozwojem zawodowym nauczycieli oraz z rolą i odpowiedzialnością kierownictwa szkół w tym zakresie. Stale obserwujemy modernizację uniwersytetów i innych instytucji szkolnictwa wyższego. Nowoczesne, silne i niezależne instytucje szkolnictwa wyższego, oferujące wysokie standardy edukacji przyczyniają się do wzmocnienia konkurencyjności, zwiększenia zatrudnienia i osiagnięcia długotrwałego zrównoważonego rozwoju. Wzrosła waga instytucji szkolnictwa wyższego w innowacjach opartych na badaniach, a ich rola w efektywnym trójkącie wiedzy (edukacja - badania - innowacje) została wzmocniona. Działania będą skoncentrowane na roli instytucji szkolnictwa wyższego w promowaniu współpracy w ramach trójkąta wiedzy. Edukacja i integracja społeczna są ważnymi problemami zarówno dla poszczególnych Państw Członkowskich, jak i dla całej Unii Europejskiej. W czasie prezydencji, rozpocznie się dyskusja na poziomie europejskim dotycząca kilku ważnych kwestii związanych z rolą edukacji w umożliwianiu emigrantom integracji z danym społeczeństwem.

\section{Młodzież - zwiększona wspólpraca promująca dobre warunki życia dla mlodych ludzi w UE}

Biorąc pod uwagę obecną sytuację demograficzna, spodziewany jest spadek odsetka młodych ludzi w nadchodzących dekadach. Udział młodych ludzi w kształceniu, w rynku pracy i w społeczeństwie jest zatem kluczowy nie tylko dla ich rozwoju jako jednostek, ale również dla zrównoważonego rozwoju i wzrostu gospodarczego Europy. Efektywna współpraca młodzieży jest jeszcze ważniejsza w obliczu obecnego kryzysu gospodarczego, który może mieć szczególnie dotkliwy wpływ na młodych ludzi. Najważniejszą kwestią w czasie szwedzkiej prezydencji będzie określenie ram przez nowe, wspólne cele i priorytety dotyczących polityki współpracy młodzieży w UE począwszy od $2010 \mathrm{r}$. Prezydencja podkreśli istotę promowania dobrych warunków życia i większego udziału młodych kobiet i mężczyzn w Europie poprzez lepszą współpracę.

\section{Kultura i media - na rzecz kreatywnego pokolenia}

Jednym z głównych wyzwań w obszarze kultury i mediów jest stworzenie dostępu do kultury i promowanie talentów i kreatywności, szczególnie wśród dzieci i ludzi młodych. Nowe sposoby konsumpcji mediów oraz nowa ekspresja kulturowa tworzą zarówno możliwości, jak i wyzwania. Ważnym zadaniem jest wzmocnienie dzieci i młodych ludzi jako konsumentów mediów. Inicjatywy wspierające kreatywność dzieci i młodzieży są podstawą stworzenia otwartej i dynamicznej Europy. W związku z powyższym, prezydencja podejmie działania zmierzające do uwzględnienia perspektywy 
dzieci i młodzieży w pracach zmierzających do zwiększenia dostępu do kultury, prawa do kulturalnej i innowacyjnej kreatywności jednostki oraz wagi sektora kreatywnego w rozwoju społeczeństwa. Ambicją prezydencji jest pomoc w promowaniu kreatywnego pokolenia poprzez skoncentrowanie się na wartościach kultury w szkołach, jak również na potencjale mediów oraz ich wyzwaniom.

\section{Ważne spotkania:}

- „Promoting a Creative Generation - a conference on children's and young people's creativity and their use of culture and media" (Promowanie kreatywnego pokolenia - konferencja na temat kreatywności dzieci i ludzi młodych oraz ich korzystania z kultury i mediów), Göteborg, 29-30 lipca.

- Konferencja „The Knowledge Triangle Shaping the Future of Europe” (Trójkąt wiedzy kształtujący przyszłość Europy), Göteborg, 31 sierpnia-2 września.

- Konferencja „Future Youth Policy Cooperation in the EU” (Przyszła polityka współpracy młodzieży w UE), Sztokholm, 12-14 września.

- Konferencja "The Role of VET in Meeting the Challenges of Today and Tomorrow" (Rola kształcenia i szkolenia zawodowego (VET) w sprostaniu wyzwaniom teraźniejszości i przyszłości), Sztokholm, 12-13 listopada.

- Konferencja „Gender Differences in Educational Achievement” (Różnice płci w osiagnięciach edukacyjnych), Uppsala, 17-18 listopada.

- Konferencja zamykająca Europejski Rok Kreatywności i Innowacji 2009, Sztokholm, 16-17 grudnia.

\section{Zalącznik: Planowane spotkania Rady podczas szwedzkiej prezydencji UE}

\section{Rada Europejska}

Rada Europejska Bruksela 29-30 października; Rada Europejska Bruksela 10-11 grudnia.

\section{Spotkania Rady Ministrów w Brukseli i Luksemburgu}

Rada ds. Gospodarczych i Finansowych (ECOFIN) Bruksela 7 lipca; Rada ECOFIN (Budżet) Bruksela 10 lipca; Rada ds. Rolnictwa i Rybołówstwa Bruksela 13-14 lipca; Rada ds. Ogólnych i Stosunków Zewnętrznych (GAERC) Bruksela 27-28 lipca; Rada ds. Ogólnych i Stosunków Zewnętrznych (GAERC) Bruksela 14-15 września; Rada ds. Wymiaru Sprawiedliwości i Spraw Wewnętrznych Bruksela 21-22 września; Rada ds. Konkurencyjności Bruksela 24-25 września; Ewentualnie: Rada ds. Rolnictwa i Rybołówstwa Bruksela 28-29 września; Rada ds. Zatrudnienia, Polityki Społecznej, Zdrowia i Spraw Konsumenckich (EPSCO), Luksemburg 1 października, Luksemburg 8-9 października; Rada ds. Rolnictwa i Rybołówstwa Luksemburg 19-20 października; Rada ds. Gospodarczych i Finansowych (ECOFIN), Luksemburg 20 października; Rada ds. Wymiaru Sprawiedliwości i Spraw Wewnętrznych. Luksemburg 23 października; Rada ds. Środowiska Naturalnego, Luksemburg 23 października; Rada ds. Ogólnych i Stosunków Zewnętrznych Luksemburg 26-27 października; Rada ds. Gospodarczych 
i Finansowych (ECOFIN) Bruksela 10 listopada; Rada ds. Ogólnych i Stosunków Zewnętrznych (z udziałem ministrów obrony i pomocy rozwojowej) Bruksela 16-17 listopada; Rada ds. Rolnictwa i Rybołówstwa Bruksela 19-20 listopada; Rada ds. Edukacji, Młodzieży i Kultury Bruksela 26-27 listopada; Rada ds. Wymiaru Sprawiedliwości i Spraw Wewnętrznych Bruksela 30 listopada -1 grudnia; Rada ds. Zatrudnienia, Polityki Społecznej, Zdrowia i Spraw Konsumenckich (EPSCO) Bruksela 30 listopada-1 grudnia; Rada ds. Gospodarczych i Finansowych Bruksela 2 grudnia; Rada ds. konkurencyjności Bruksela 3-4 grudnia Rada ds. Ogólnych i Stosunków Zewnętrznych Bruksela 7-8 grudnia; Rada ds. Rolnictwa i Rybołówstwa Bruksela 14-15 grudnia, Bruksela 17-18 grudnia; Rada ds. środowiska naturalnego Bruksela 22 grudnia.

W dokumencie nie ujęto nieformalnych spotkań ministrów w Szwecji. 